\title{
Cardiovascular "Patterns" of $\mathrm{H}_{2} \mathrm{~S}$ and SSNO--Mix Evaluated from 35 Rat Hemodynamic Parameters
}

\author{
Lenka Tomasova $^{1,+}+\mathbb{D}$, Marian Grman ${ }^{1,+} \mathbb{D}$, Anton Misak ${ }^{1} \mathbb{D}$, Lucia Kurakova ${ }^{2} \mathbb{D}$, Elena Ondriasova ${ }^{2}$ \\ and Karol Ondrias $1, *$ (D) \\ 1 Biomedical Research Center, Institute of Clinical and Translational Research, Slovak Academy of Sciences, \\ 81104 Bratislava, Slovakia; lenka.tomasova@savba.sk (L.T.); marian.grman@savba.sk (M.G.); \\ anton.misak@savba.sk (A.M.) \\ 2 Department of Pharmacology and Toxicology, Faculty of Pharmacy, Comenius University, \\ 81499 Bratislava, Slovakia; kurakova4@uniba.sk (L.K.); ondriasova@fpharm.uniba.sk (E.O.) \\ * Correspondence: karol.ondrias@savba.sk; Tel.: +421-908577943 \\ + These authors contributed equally to this work.
}

Citation: Tomasova, L.; Grman, M.; Misak, A.; Kurakova, L.; Ondriasova,

E.; Ondrias, K. Cardiovascular "Patterns" of $\mathrm{H}_{2} \mathrm{~S}$ and $\mathrm{SSNO}^{-}$-Mix Evaluated from 35 Rat Hemodynamic Parameters. Biomolecules 2021, 11, 293. https://doi.org/10.3390/ biom11020293

Academic Editor: Sona Cacanyiova

Received: 13 January 2021

Accepted: 10 February 2021

Published: 16 February 2021

Publisher's Note: MDPI stays neutral with regard to jurisdictional claims in published maps and institutional affiliations.

Copyright: (C) 2021 by the authors. Licensee MDPI, Basel, Switzerland. This article is an open access article distributed under the terms and conditions of the Creative Commons Attribution (CC BY) license (https:/ / creativecommons.org/licenses/by/ $4.0 /)$.

\begin{abstract}
This work is based on the hypothesis that it is possible to characterize the cardiovascular system just from the detailed shape of the arterial pulse waveform (APW). Since $\mathrm{H}_{2} \mathrm{~S}$, $\mathrm{NO}$ donor S-nitrosoglutathione (GSNO) and their $\mathrm{H}_{2} \mathrm{~S} / \mathrm{GSNO}$ products ( $\mathrm{SSNO}^{-}$-mix) have numerous biological actions, we aimed to compare their effects on APW and to find characteristic "patterns" of their actions. The right jugular vein of anesthetized rats was cannulated for i.v. administration of the compounds. The left carotid artery was cannulated to detect APW. From APW, 35 hemodynamic parameters (HPs) were evaluated. $\mathrm{H}_{2} \mathrm{~S}$ transiently influenced all $35 \mathrm{HPs}$ and from their crossrelationships to systolic blood pressure "patterns" and direct/indirect signaling pathways of the $\mathrm{H}_{2} \mathrm{~S}$ effect were proposed. The observed "patterns" were mostly different from the published ones for GSNO. Effect of SSNO ${ }^{-}$-mix $\left(\leq 32 \mathrm{nmol} \mathrm{kg}^{-1}\right)$ on blood pressure in the presence or absence of a nitric oxide synthase inhibitor (L-NAME) was minor in comparison to GSNO, suggesting that the formation of $\mathrm{SSNO}^{-}$-mix in blood diminished the hemodynamic effect of NO. The observed time-dependent changes of $35 \mathrm{HPs}$, their cross-relationships and non-hysteresis/hysteresis profiles may serve as "patterns" for the conditions of a transient decrease/increase of blood pressure caused by $\mathrm{H}_{2} \mathrm{~S}$.
\end{abstract}

Keywords: sulfide; nitric oxide; nitrosopersulfide; arterial pulse waveform; blood pressure; hemodynamic parameters; signaling pathways

\section{Introduction}

The information obtained from arterial pulse waveform (APW) analysis can provide insight into the function of the cardiovascular system in physiological and pathophysiological conditions. Several APW parameters were shown to be useful for the characterization of the cardiovascular system [1-3]. Recently, we introduced the evaluation of 35 parallel time-dependent rat hemodynamic parameters (HPs) from recorded APW at a high resolution [4-6]. From the cross-relationships of the $35 \mathrm{HPs}$, one can obtain 595 "patterns" characterizing cardiovascular system at the given conditions. In the cases when changes of HPs are transient, non-hysteresis/hysteresis "patterns" can be evaluated from the cross-relationships that may indicate direct or indirect connections of signaling pathways between two given HPs [4,5].

The present work is a continuation of our work based on the hypothesis that it is possible to characterize the cardiovascular system in many patho-physiological conditions from the detailed shape of APW. The HPs and their cross-relationships may provide "patterns" for particular cardiovascular conditions, as we obtained the conditions of decrease/increase of NO bioavailability [4-6]. 
Since endogenously produced gasotransmitters, hydrogen sulfide $\left(\mathrm{H}_{2} \mathrm{~S}\right)$ and nitric oxide (NO), and the products of $\mathrm{H}_{2} \mathrm{~S} / \mathrm{NO}$ interactions (referred as $\mathrm{SSNO}^{-}$-mix) influence various physiological processes, particularly regulate blood pressure (BP) [7-17], it was of interest to study the effects of $\mathrm{H}_{2} \mathrm{~S}$ and $\mathrm{SSNO}^{-}$-mix on $35 \mathrm{HPs}$ and subsequently compare the selected cross-relationships of the HPs and their non-hysteresis/hysteresis "patterns" to the published data for NO-donor S-nitrosoglutathione (GSNO) [4].

We found that the intravenous (i.v.) administration of $\mathrm{H}_{2} \mathrm{~S}$ transiently influenced all $35 \mathrm{HPs}$ in anesthetized rats and from the cross-relationships of the HPs to the systolic BP, "patterns" and direct/indirect signaling pathways of the $\mathrm{H}_{2} \mathrm{~S}$ effects on hemodynamics were proposed. The observed "patterns" after $\mathrm{H}_{2} \mathrm{~S}$ administration were mostly different from the "patterns" observed after GSNO administration [4]. The effect of $\mathrm{SSNO}^{-}-\mathrm{mix}$ $\left(\leq 32 \mathrm{nmol} \mathrm{kg}^{-1}\right)$ on BP in the presence or absence of an inhibitor of nitric oxide synthase L-NAME was minor in comparison to GSNO, suggesting that the formation or presence of $\mathrm{SSNO}^{-}$-mix products in blood may diminish the hemodynamic effects of NO.

\section{Materials and Methods}

\subsection{Chemicals}

$\mathrm{Na}_{2} \mathrm{~S}$ was purchased from DoJindo (SB01, Munich, Germany), and other chemicals were purchased from Sigma-Aldrich (Steinheim, Germany). $\mathrm{Na}_{2} \mathrm{~S}$ dissociates in the solution and reacts with $\mathrm{H}^{+}$to yield $\mathrm{H}_{2} \mathrm{~S}, \mathrm{HS}^{-}$and traces of $\mathrm{S}^{2-}$. We use the term " $\mathrm{H}_{2} \mathrm{~S}^{\prime}$ to encompass the total mixture of $\mathrm{H}_{2} \mathrm{~S}, \mathrm{HS}^{-}$and $\mathrm{S}^{2-}$. Stock solution of $100 \mathrm{mM} \mathrm{Na}_{2} \mathrm{~S}$ was prepared in argon-bubbled ultrapure deionized $\mathrm{H}_{2} \mathrm{O}$ and stored at $-80{ }^{\circ} \mathrm{C}$. It was thawed and diluted with $0.9 \% \mathrm{NaCl}$ to the final concentration just before the i.v. administration. GSNO was freshly prepared in $0.9 \% \mathrm{NaCl}$ before i.v. administration from a stock $10 \mathrm{mmol} \mathrm{L}{ }^{-1} \mathrm{GSNO}$ prepared in ultrapure deionized water and stored at $-80{ }^{\circ} \mathrm{C}$. The products of the $\mathrm{H}_{2} \mathrm{~S} / \mathrm{GSNO}$ interaction $\left(\mathrm{SSNO}^{-}\right.$-mix) were prepared by mixing of $20 \mu \mathrm{L}$ of $10 \mathrm{mmol} \mathrm{L}^{-1}$ GSNO (in $\mathrm{H}_{2} \mathrm{O}$ ) and $20 \mu \mathrm{L}$ of $100 \mathrm{mmol} \mathrm{L}^{-1} \mathrm{Na}_{2} \mathrm{~S}$ (in $\mathrm{H}_{2} \mathrm{O}$ ) in $160 \mu \mathrm{L}$ buffer $\left(200 \mathrm{mmol} \mathrm{L}{ }^{-1}\right.$ Tris. $\left.\mathrm{HCl}, \mathrm{pH} 7.4\right)$ at $22 \pm 1.5^{\circ} \mathrm{C}$. Product formation was monitored by UV-VIS spectrophotometry (absorbance increase at $\lambda_{\max } 412 \mathrm{~nm}$ corresponds to the $\mathrm{SSNO}^{-}$formation), and the reaction was completed within $3 \mathrm{~min}$, followed by the dilution of the mixture with $0.9 \% \mathrm{NaCl}$ to the final concentration just before the i.v. administration. Since SSNO- ${ }^{-}$was proposed to be the major longer-lived product of the sulfide and S-nitrosothiols reaction [14,18,19], we hereinafter refer to the products of the reaction mixture as the "SSNO ${ }^{-}$-mix". The concentration of the $\mathrm{SSNO}^{-}$-mix is defined as the initial concentration of GSNO in the mixture when the reaction time equals zero.

\subsection{Ethical Approval}

All procedures were approved by the State Veterinary and Food Administration of the Slovak Republic (C.k. Ro 3123/17-221) according to the guidelines from Directive 2010/63/EU of the European Parliament. The procuration of animals, the husbandry and the experiments conformed to the "European Convention for the Protection of Vertebrate Animals used for Experimental and other Scientific Purposes" (Council of Europe No 123, Strasbourg 1985). Experiments were carried out according to the guidelines laid down by the animal welfare committee of the Biomedical Research Center, Slovak Academy of Sciences, Bratislava and conformed to the principles and regulations, as described in the Editorial by Grundy [20]. The animals were under anesthesia throughout the duration of the experiment and were euthanized with an overdose of Zoletil/Xylazine via the jugular vein at the end of the surgical procedure. 


\subsection{Animals, APW Measurement and Data Evaluation}

The method was essentially described in our previous studies [4-6]. We follow the principle of not implementing any more animals as is necessary in order to minimize animal use according to the principles of the National Centre for the Replacement, Refinement and Reduction of Animals in Research (NC3Rs, London, UK). Male Wistar rats $(\mathrm{n}=17 ; 330 \pm 40 \mathrm{~g}$ ) were purchased from the Department of Toxicology and Laboratory Animal Breeding at Dobra Voda, Slovak Academy of Sciences, Slovakia. The rats were housed under a $12 \mathrm{~h}$ light-12 h-dark cycle, at a constant humidity $(45-65 \%)$ and temperature $\left(20-22{ }^{\circ} \mathrm{C}\right)$, with free access to standard laboratory rat chow and drinking water. The veterinary nursing care was provided by the Central Animal Housing Facility of Pavilion of Medical Sciences (registration number SK UCH 01017). In the experiments with $10 \mu \mathrm{mol} \mathrm{kg}^{-1} \mathrm{H}_{2} \mathrm{~S}$, eight rats were anesthetized with Zoletil 100 (tiletamine + zolazepam, $80 \mathrm{mg} \mathrm{kg}^{-1}$, i.p.) and Xylazine (5 mg kg-1 i.p.). In the experiments, where we compared the effects of $\mathrm{H}_{2} \mathrm{~S}$, GSNO and $\mathrm{SSNO}^{-}$-mix on the same rat, long time ( $\left.100 \mathrm{~min}\right)$ anesthesia was necessary. Therefore, nine rats were anesthetized with Zoletil 100 (tiletamine + zolazepam, $60 \mathrm{mg} \mathrm{kg}^{-1}$, i.p.) and Xylazine (5 $\mathrm{mg} \mathrm{kg}^{-1}$, i.p.), and just before surgical operation, the same anesthetic dose were administrated again. For notice, $\mathrm{H}_{2} \mathrm{~S}$, GSNO or $\mathrm{SSNO}^{-}$-mix were administered into the right jugular vein $\left(500 \mu \mathrm{L} \mathrm{kg}^{-1}\right)$ over a $15 \mathrm{~s}$ period, about $40-50 \mathrm{~min}$ after the first anesthetic application. L-NAME $\left(25 \mathrm{mg} \mathrm{kg}^{-1}\right.$, prepared in $0.9 \%$ saline solution) was used to study the hemodynamic effects of $\mathrm{H}_{2} \mathrm{~S}$, GSNO or $\mathrm{SSNO}^{-}$-mix in the condition of low NO bioavailability and high BP. The left common carotid artery (arteria carotis communis) was cannulated to insert the fiber-optic microcatheter pressure transducer FISO LS 2F connected to the FISO Series Signal Conditioner embedded in the EVO Chassis (Harvard Apparatus, Holliston, MA, USA). The recorded analog APW signal was filtered by a lowpass filter at $1 \mathrm{kHz}$, digitalized at $10 \mathrm{kHz}$ and stored on a computer. Ten points (a-j) of APW, marked in Figure S1, were analyzed, from which $35 \mathrm{HP}$ parameters were calculated as in our published studies [4-6]. Definition and abbreviation of the $35 \mathrm{HP}$ parameters are described in detail in the Supplementary Materials (Figure S1). Since point a, resp. j fluctuated with time interval $\sim 5-10 \mathrm{~ms}$ and $\sim 1 \mathrm{mmHg}$ BP (Figure S1B), when it was necessary, the data were filtered to average the fluctuation. For better visual comparison, plots (a) and (aa) presenting systolic BP in Figures are the same. The plot of augmentation index relative (e.g., Figure 1ji) was not possible to determine in cases when the highest point at APW (Figure S1A) was " $\mathrm{c}$ " and not "f" (for details see Reference [4]). 

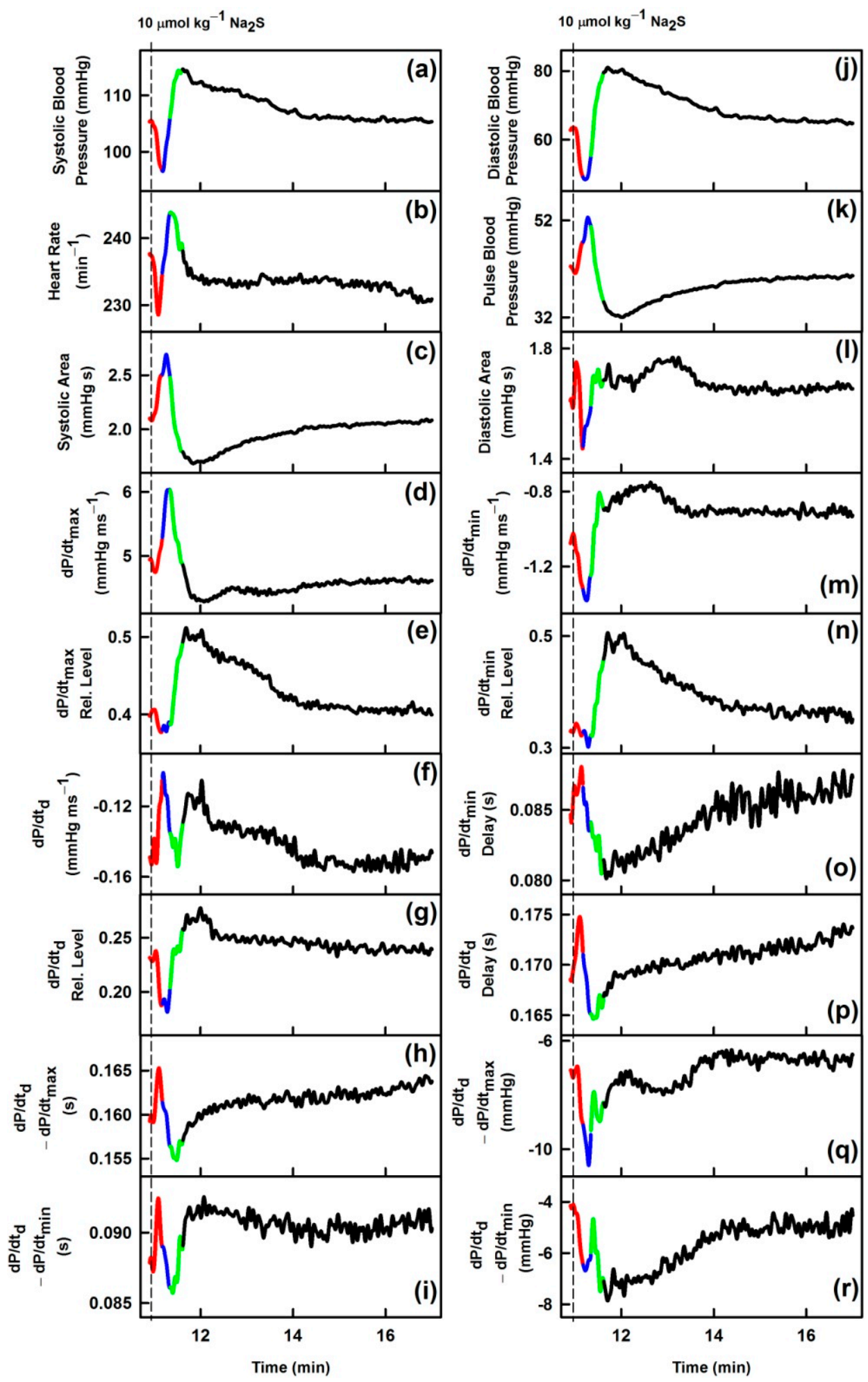

Figure 1. Cont. 

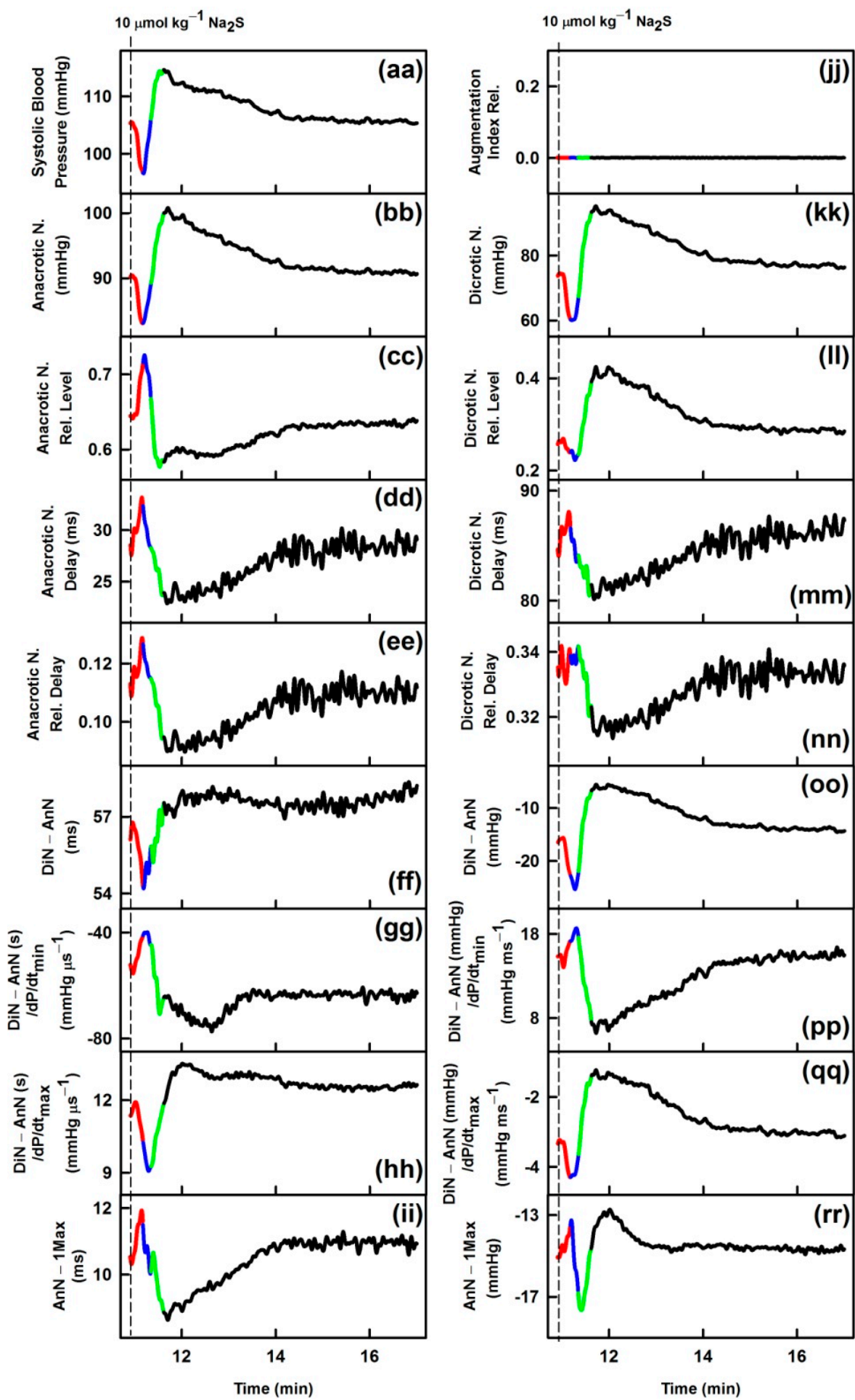

Figure 1. Time-dependent changes of hemodynamic parameters (HPs) of anesthetized rat after i.v. bolus administration of $10 \mu \mathrm{mol} \mathrm{kg}{ }^{-1} \mathrm{Na}_{2} \mathrm{~S}$ (marked by dash lines). The red line starts $3 \mathrm{~s}$ before $\mathrm{Na}_{2} \mathrm{~S}$ administration. Colors: time period corresponding to the decrease of systolic BP (red), increase of systolic BP to the control value (blue), further increase of systolic BP to the maximum (green) and decrease of systolic BP to the control value (black). For the explanation of (a), (b) ... (rr) plots see the Description of the Table 1 and Figure S1. Units in plots (gg), (hh), (pp) and (qq) are informative only. 
Table 1. Comparison of the time-dependent transient effects of $10 \mu \mathrm{mol} \mathrm{kg}{ }^{-1} \mathrm{H}_{2} \mathrm{~S}$ (at least 6 out of 8 rats) on 35 HPs (red lines in Figure 1 and Figures S2-S8) and $32 \mathrm{nmol} \mathrm{kg}^{-1}$ GSNO (data from Figure 6, Table 1 in Reference [4]).

\begin{tabular}{|c|c|c|c|}
\hline & Description & GSNO & $\mathrm{Na}_{2} \mathrm{~S}$ \\
\hline (a) & Systolic blood pressure; in $\mathrm{mmHg}$ & $\downarrow$ & $\downarrow$ \\
\hline (b) & Heart rate; in $\min ^{-1}$ & $\sim$ & $\downarrow$ \\
\hline (c) & Systolic area; in mmHg s & $\uparrow$ & $\uparrow$ \\
\hline (d) & $\mathrm{dP} / \mathrm{dt}_{\max } ;$ in $\mathrm{mmHg} \mathrm{ms}{ }^{-1}$ & $\uparrow$ & $\sim$ \\
\hline (e) & $\mathrm{dP} / \mathrm{dt}_{\max }$ relative level & $\downarrow$ & $\downarrow$ \\
\hline (f) & $\mathrm{dP} / \mathrm{dt}_{\mathrm{d}} ;$ in $\mathrm{mmHg} \mathrm{ms}{ }^{-1}$ & $\downarrow \uparrow$ & $\sim$ \\
\hline (g) & $\mathrm{dP} / \mathrm{dt}_{\mathrm{d}}$ relative level & $\downarrow$ & $\downarrow$ \\
\hline (h) & $\mathrm{dP} / \mathrm{dt}_{\mathrm{d}}-\mathrm{dP} / \mathrm{dt}_{\max } ;$ in $\mathrm{s}$ & $\uparrow$ & $\uparrow$ \\
\hline (i) & $\mathrm{dP} / \mathrm{dt}_{\mathrm{d}}-\mathrm{dP} / \mathrm{dt}_{\min } ;$ in $\mathrm{s}$ & $\uparrow \downarrow$ & $\uparrow$ \\
\hline (j) & Diastolic blood pressure; in $\mathrm{mmHg}$ & $\downarrow$ & $\downarrow$ \\
\hline$(\mathrm{k})$ & Pulse blood pressure; in $\mathrm{mmHg}$ & $\uparrow$ & $\uparrow$ \\
\hline (l) & Diastolic area; in $\mathrm{mmHg} \mathrm{s}$ & $\downarrow$ & $\uparrow$ \\
\hline (m) & $\mathrm{dP} / \mathrm{dt}_{\min } ;$ in $\mathrm{mmHg} \mathrm{ms}{ }^{-1}$ & $\downarrow$ & $\downarrow$ \\
\hline (n) & $\mathrm{dP} / \mathrm{dt}_{\min }$ relative level & $\downarrow$ & $\sim$ \\
\hline (o) & $\mathrm{dP} / \mathrm{dt}_{\min }$ delay; in $\mathrm{s}$ & $\uparrow$ & $\uparrow$ \\
\hline (p) & $\mathrm{dP} / \mathrm{dt}_{\mathrm{d}}$ delay; in $\mathrm{s}$ & $\uparrow$ & $\uparrow$ \\
\hline (q) & $\mathrm{dP} / \mathrm{dt}_{\mathrm{d}}-\mathrm{dP} / \mathrm{dt}_{\max } ;$ in $\mathrm{mmHg}$ & $\downarrow$ & $\downarrow$ \\
\hline$(\mathrm{r})$ & $\mathrm{dP} / \mathrm{dt}_{\mathrm{d}}-\mathrm{dP} / \mathrm{dt}_{\min } ;$ in $\mathrm{mmHg}$ & $\uparrow$ & $\sim$ \\
\hline (aa) & Systolic blood pressure; in $\mathrm{mmHg}$ & $\downarrow$ & $\downarrow$ \\
\hline (bb) & Anacrotic notch; in $\mathrm{mmHg}$ & $\downarrow$ & $\downarrow$ \\
\hline (cc) & Anacrotic notch relative level & $\uparrow$ & $\uparrow$ \\
\hline (dd) & Anacrotic notch delay; in ms & $\uparrow$ & $\uparrow$ \\
\hline (ee) & Anacrotic notch relative Delay & $\uparrow$ & $\sim$ \\
\hline$(\mathrm{ff})$ & Dicrotic notch (DiN) - Anacrotic notch (AnN); in s & $\uparrow$ & $\uparrow$ \\
\hline (gg) & $(\mathrm{DiN}-\mathrm{AnN}) / \mathrm{dP} / \mathrm{dt}_{\mathrm{min}} ;$ in $\mathrm{s} / \mathrm{mmHg} \mu \mathrm{s}^{-1}$ & $\uparrow$ & $\uparrow$ \\
\hline (hh) & $(\mathrm{DiN}-\mathrm{AnN}) / \mathrm{dP} / \mathrm{dt}_{\max } ;$ in $\mathrm{s} / \mathrm{mmHg}_{\mu \mathrm{s}}-1$ & $\downarrow$ & $\sim$ \\
\hline (ii) & $\mathrm{AnN}-1 \mathrm{Max}$; in $\mathrm{ms}$ & $\uparrow$ & $\uparrow$ \\
\hline (jj) & Augmentation index relative & $\sim$ & $\sim$ \\
\hline$(\mathrm{kk})$ & Dicrotic notch; in mmHg & $\downarrow$ & $\downarrow$ \\
\hline$(11)$ & Dicrotic notch relative level & $\downarrow$ & $\downarrow$ \\
\hline$(\mathrm{mm})$ & Dicrotic notch delay; in ms & $\uparrow$ & $\uparrow$ \\
\hline$(\mathrm{nn})$ & Dicrotic notch relative delay & $\uparrow$ & $\sim$ \\
\hline$(\mathrm{oo})$ & $\mathrm{DiN}-\mathrm{AnN}$; in $\mathrm{mmHg}$ & $\downarrow$ & $\downarrow$ \\
\hline (pp) & $(\mathrm{DiN}-\mathrm{AnN}) / \mathrm{dP} / \mathrm{dt}_{\min } ;$ in $\mathrm{mmHg} / \mathrm{mmHg} \mathrm{ms}^{-1}$ & $\uparrow$ & $\uparrow$ \\
\hline (qq) & $(\mathrm{DiN}-\mathrm{AnN}) / \mathrm{dP} / \mathrm{dt}_{\max } ;$ in $\mathrm{mmHg} / \mathrm{mmHg} \mathrm{ms}^{-1}$ & $\downarrow$ & $\downarrow$ \\
\hline$(\mathrm{rr})$ & $\mathrm{AnN}-1 \mathrm{Max}$; in $\mathrm{mmHg}$ & $\sim$ & $\sim$ \\
\hline
\end{tabular}

\section{Results}

\subsection{Effects of $\mathrm{Na}_{2} \mathrm{~S}$ on Time-Dependent Changes of $35 \mathrm{HPS}$}

The time-dependent changes of $35 \mathrm{HPs}$ after i.v. bolus administration of $10 \mu \mathrm{mol} \mathrm{kg}-1$ $\mathrm{Na}_{2} \mathrm{~S}$ are shown in Figure 1 and for other seven rats in Figures S2-S8. $\mathrm{Na}_{2} \mathrm{~S}$ affected all $35 \mathrm{HPs}$ for the period of $\sim 5-10 \mathrm{~min}$ and then the values of HPs returned to the control level. To compare the changes of the $35 \mathrm{HPs}$, the time dependency of all HPs was divided into four phases according to the systolic BP curve (Figure 1a): decrease of systolic BP (red), increase to the control value (blue), further increase to maximum BP (green) and final decrease to the control value (black). From the comparison of the phases, it is evident that most of the HPs did not follow the time-dependent changes of systolic BP after the administration of $\mathrm{Na}_{2} \mathrm{~S}$. Some of the HPs followed similar (but not identical) or reverse time-dependent changes as systolic BP (a). However, other HPs, e.g., systolic area (c), $\mathrm{dP} / \mathrm{dt}_{\max }(\mathrm{d}), \mathrm{dP} / \mathrm{dt}_{\max }-\mathrm{RL}(\mathrm{e}), \mathrm{dP} / \mathrm{dt}_{\mathrm{d}}(\mathrm{f}), \mathrm{dP} / \mathrm{dt}_{\mathrm{d}}-\mathrm{RL}(\mathrm{g})$, diastolic area $(\mathrm{l}), \mathrm{dP} / \mathrm{dt}_{\min }-\mathrm{RL}$ (n), $\mathrm{dP} / \mathrm{dt}_{\mathrm{d}}-\mathrm{dP} / \mathrm{dt}_{\max }(\mathrm{q}), \mathrm{dP} / \mathrm{dt}_{\mathrm{d}}-\mathrm{dP} / \mathrm{dt}_{\min }(\mathrm{r}), \operatorname{DiN}-\mathrm{RD}(\mathrm{nn}),(\mathrm{DiN}-\mathrm{AnN}) / \mathrm{dP} / \mathrm{dt}_{\min }$ (pp), and (DiN - AnN)/dP/dt max (qq) showed a completely different course in time, 
suggesting that these APW changes are activated at different time points and probably by different signaling pathways than the changes in systolic BP.

\subsection{Comparison of Transient Effects of $\mathrm{Na}_{2} \mathrm{~S}$ with Published Data of GSNO on 35 HPS}

In our previous studies, we evaluated time-dependent changes of $35 \mathrm{HPs}$ in the condition of increased NO bioavailability by GSNO and compared these effects with the changes observed in the condition of decreased NO biovailability by L-NAME [4,5]. Since GSNO transiently decreased systolic BP, similarly to $\mathrm{H}_{2} \mathrm{~S}$, we compared trends of their effects on $35 \mathrm{HPs}$ during the decrease of systolic BP (Table 1). The comparison revealed that the time-dependent trends of $25 \mathrm{HPs}$ were similar for both compounds. The diastolic area (l) was affected in the opposite direction, GSNO decreased and $\mathrm{Na}_{2} \mathrm{~S}$ increased this $\mathrm{HP}$ (red). The remaining $9 \mathrm{HPs}$ showed different correlations, e.g., increase/decrease vs no effect for heart rate (b), $\mathrm{dP} / \mathrm{dt}_{\max }(\mathrm{d}), \mathrm{dP} / \mathrm{dt}_{\min }-\mathrm{RL}(\mathrm{n}), \mathrm{dP} / \mathrm{dt}_{\mathrm{d}}-\mathrm{dP} / \mathrm{dt}_{\min }(\mathrm{r}), \mathrm{AnN}-\mathrm{RD}$ (ee), $(\mathrm{DiN}-\mathrm{AnN}) / \mathrm{dP} / \mathrm{dt}_{\max }(\mathrm{hh}), \operatorname{DiN}-\mathrm{RD}(\mathrm{nn})$ (blue); biphasic effect vs. no effect for $\mathrm{dP} / \mathrm{dt}_{\mathrm{d}}$ (f) (green) and biphasic effect $v s$ increase for $\mathrm{dP} / \mathrm{dt}_{\mathrm{d}}-\mathrm{dP} / \mathrm{dt}_{\min }$ (i) (brown). Reproducibility of the effects of $\mathrm{Na}_{2} \mathrm{~S}$ on HPs was significantly lower than the reproducibility of the effects for NO-synthase inhibitor L-NAME and NO-donor GSNO [4,6].

\subsection{Non-Hysteresis/Hysteresis Relationships between HPs to Systolic BP after $\mathrm{Na}_{2} \mathrm{~S}$ Administration}

In order to describe "patterns" of effects of $\mathrm{Na}_{2} \mathrm{~S}$ on the cardiovascular system in more detail, time-dependent changes between systolic BP and other HPs, described as their cross-relationships, were evaluated. For the full description of the cross-relationships of the $34 \mathrm{HPs}$ to systolic BP (mmHg) each plot in Figure 2 should be three-dimensional, which we found visually confusing. Therefore, we omitted the time dimension and presented two-dimensional cross-relationships only.

From the maximum sum of 595 derived relationships between each HP, the crossrelationships between $34 \mathrm{HPs}$ and the systolic BP are shown only (Figure 2 and Figures S9-S15). The "patterns" were different for each relationship and their reproducibility for the eight rats was low. These cross-relationships showed hysteresis or non-hysteresis "patterns". We evaluated the hysteresis/non-hysteresis pattern during the time period corresponding to the decrease (Figure 2; red lines) and increase of systolic BP (Figure 2; blue lines) after $\mathrm{Na}_{2} \mathrm{~S}$ administration. The non-hysteresis cross-relationships mean that the changes of HP during the decrease (Figure 2; red lines) and increase of systolic BP (Figure 2; blue lines) followed approximately the same line in opposite directions (e.g., Figure 2; plots (dd) or (ee)). However, the hysteresis cross-relationships mean that the changes of HP during the decrease and increase of systolic BP did not follow the same line in opposite directions and form a loop $>5 \mathrm{mmHg}$ of systolic BP (e.g., Figure 2; plots (p) or (q)). Similarly, one can reconsider the non-hysteresis/hysteresis cross-relationships of the response of the cardiovascular system to the administration of $\mathrm{Na}_{2} \mathrm{~S}$ during the increase of systolic BP to maximum (Figure 2; green lines) and decrease of systolic BP to the control value (Figure 2; black lines).

Figure 3 shows the number of rats, which represent the non-hysteresis or hysteresis cross-relationship of $34 \mathrm{HPs}$ to the decrease/increase of systolic BP (data were taken from Figure 2 and Figures S9-S15, red and blue lines). There was a low reproducibility of the non-hysteresis/hysteresis cross-relationships in eight rats. The non-hysteresis crossrelationships (at least in 6 of 8 rats) were observed in plots: (e), (o), (cc), (dd) and (mm). The hysteresis cross-relationships (at least in 6 of 8 rats) were observed in plots: (c), (d), (j), (k), (q), (hh) and (rr). 

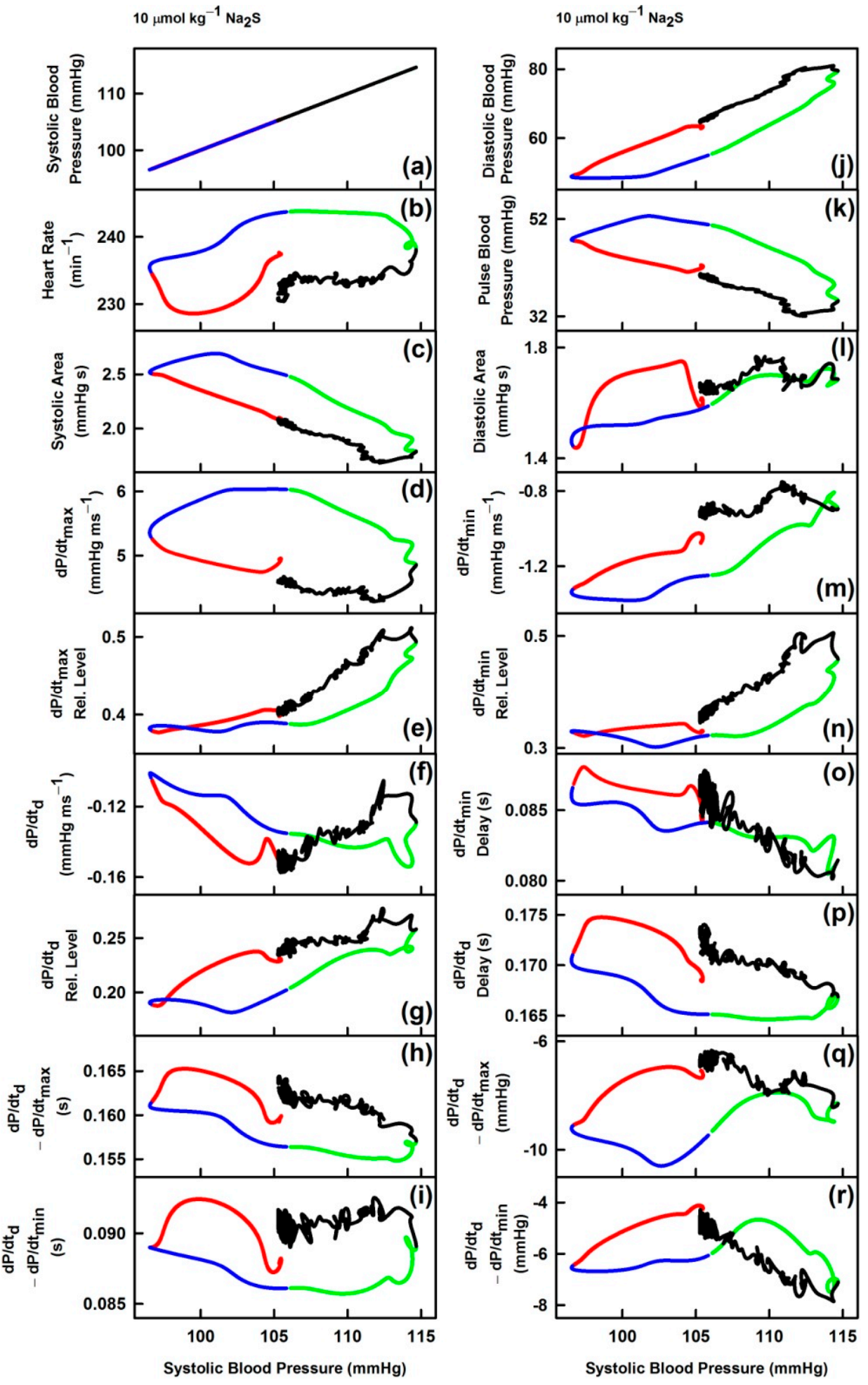

Figure 2. Cont. 

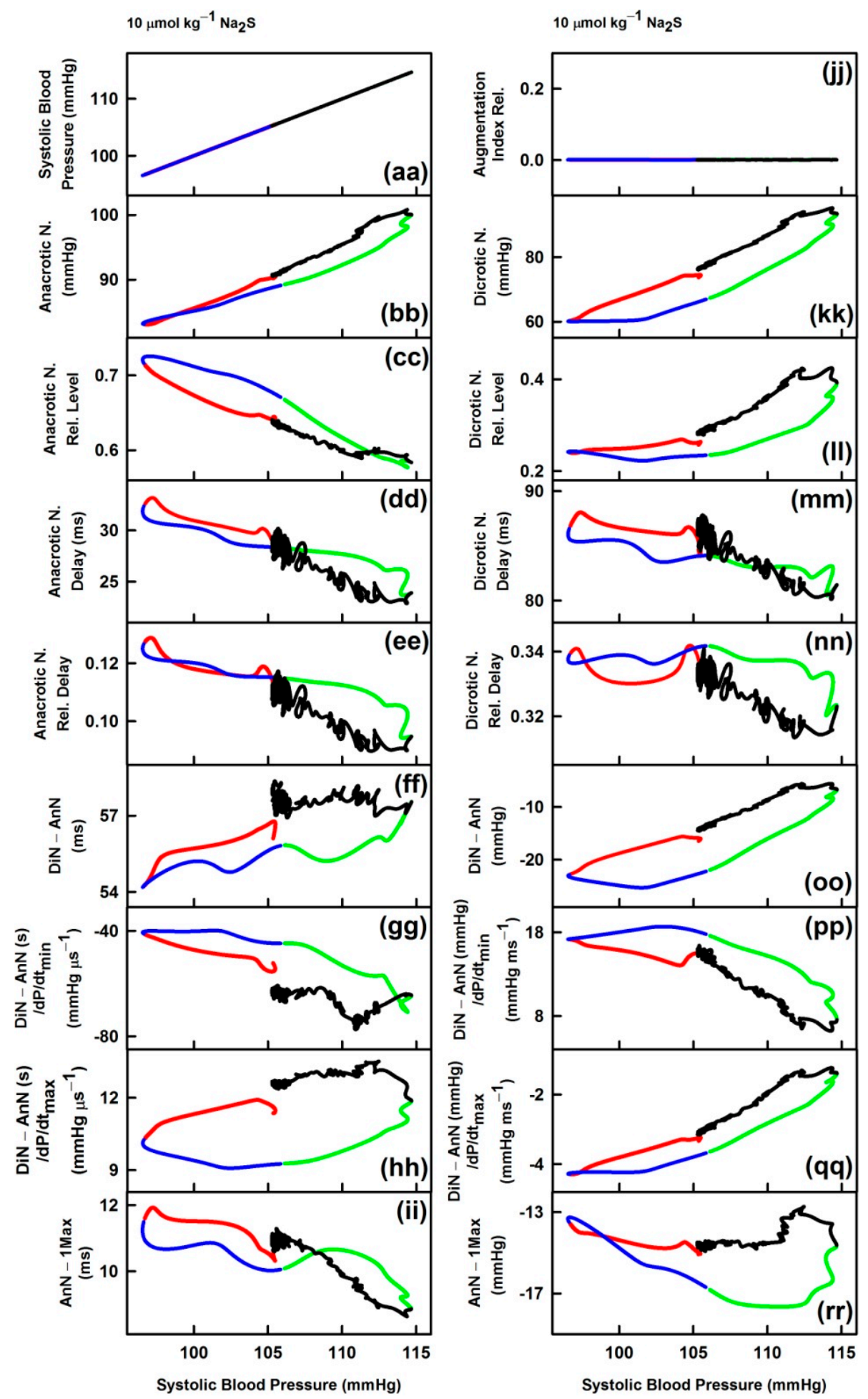

Figure 2. Relationships of HPs to the systolic BP after the administration of $10 \mu \mathrm{mol} \mathrm{kg}{ }^{-1} \mathrm{Na}_{2} \mathrm{~S}$. The colors and time-dependent data correspond to Figure 1. Time period corresponds to the decrease of systolic BP (red), increase of systolic BP to the control value (blue), further increase of systolic BP to maximum (green), and decrease of systolic BP to the control value (black). The hysteresis was arbitrarily defined as $\mathrm{HP}$ - systolic BP (in $\mathrm{mmHg}$ ) loop $>5 \mathrm{mmHg}$ of systolic BP. For the explanation of (a), (b) ... (rr) plots see the Description of the Table 1 and Figure S1. Units in plots (gg), (hh), (pp) and (qq) are informative only. 


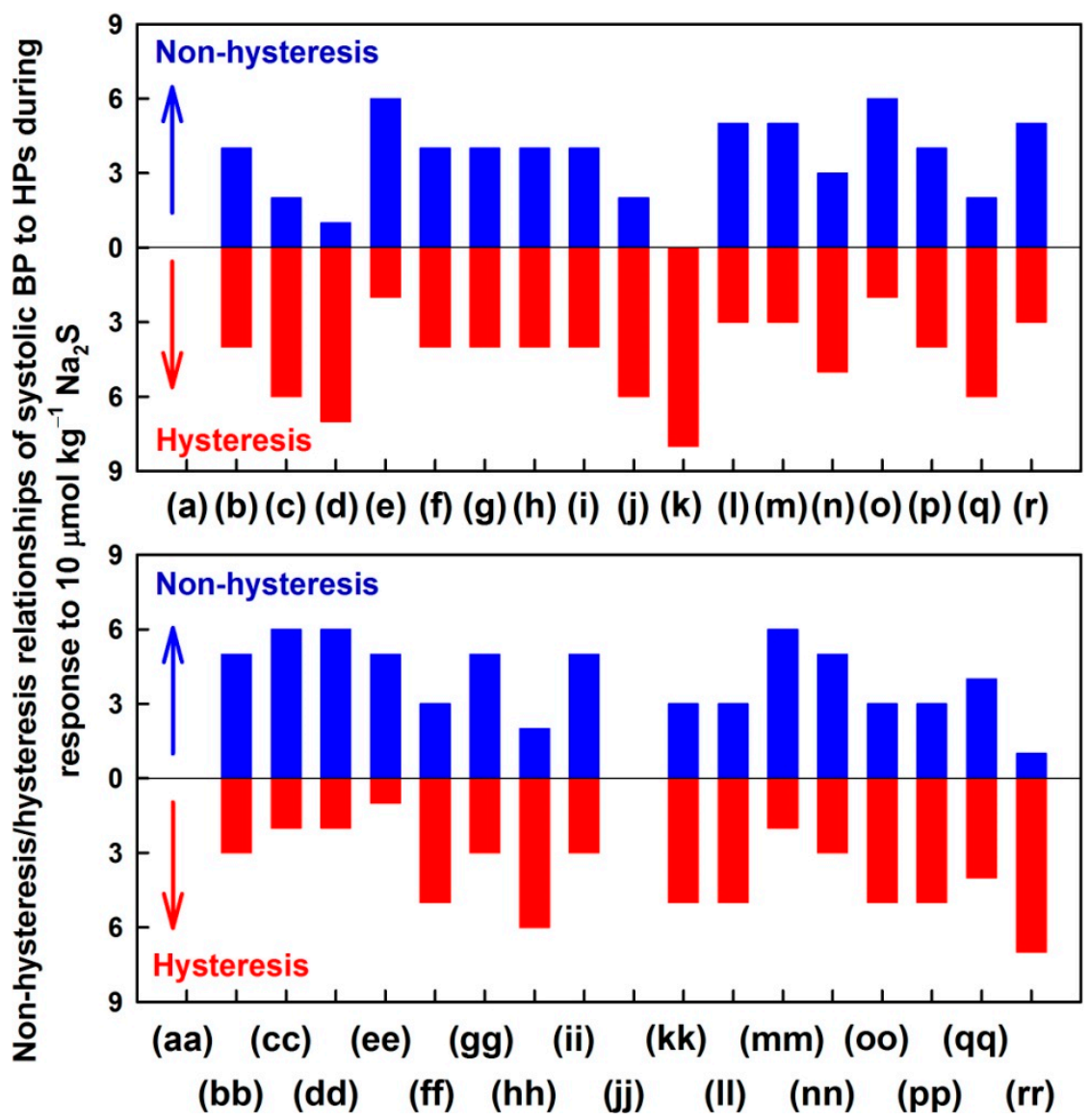

Figure 3. Number of rats, that represent the non-hysteresis or hysteresis "patterns" of the relationships of HPs to the systolic BP after the administrations of $10 \mu \mathrm{mol} \mathrm{kg}{ }^{-1} \mathrm{Na}_{2} \mathrm{~S}$ during decrease (red line in Figures 1 and 2) and increase (blue line in Figures 1 and 2) of BP. Data were taken from Figure 2 and Figures S9-S15. The total number of rats in which non-hysteresis (blue) or hysteresis (red) "patterns" were evaluated is $\mathrm{n}=8$. The hysteresis was arbitrary defined as HP - systolic BP loop $>5 \mathrm{mmHg}$ of systolic BP. For the explanation of (a), (b) ... (rr) plots see the Description of the Table 1 and Figure S1.

Since $\mathrm{H}_{2} \mathrm{~S}$ transiently decreased systolic $\mathrm{BP}$, similarly to NO-donor GSNO, we compared the $\mathrm{H}_{2} \mathrm{~S}$ data from Figure 3 to the published GSNO data (Figure 3c in Reference [4]). From the comparison of the $\mathrm{H}_{2} \mathrm{~S}$ and GSNO non-hysteresis/hysteresis cross-relationship "patterns" of the 34 HPs to systolic BP, it is evident that most of the "patterns" are not the same-actually, some of them are opposite. For example, in the $\mathrm{dP} / \mathrm{dt}_{\max }$ to the systolic BP (plot (d)), hysteresis was observed in the case of $\mathrm{H}_{2} \mathrm{~S}$, but non-hysteresis in the case of GSNO response. Similarly, opposite non-hysteresis/hysteresis relationships were observed for diastolic BP (j), pulse BP (k) or $\mathrm{dP} / \mathrm{dt}_{\mathrm{d}}-\mathrm{dP} / \mathrm{dt}_{\max }(\mathrm{q})$. However, similar non-hysteresis / hysteresis relationships for $\mathrm{H}_{2} \mathrm{~S}$ and GSNO were observed for $\mathrm{dP} / \mathrm{dt}_{\max }-\mathrm{RL}$ (e), (DiN - AnN)/dP/dt $t_{\max }$ (hh) or AnN - 1Max (rr).

Figure S16 represents the non-hysteresis/hysteresis "patterns" of the relationships of HPs to systolic BP, which were evaluated during the increase and decrease of BP (Figure 2 and Figures S9-S15, green and black lines, respectively) after the i.v. administration of $10 \mu \mathrm{mol} \mathrm{kg}{ }^{-1} \mathrm{Na}_{2} \mathrm{~S}$. The non-hysteresis cross-relationships (at least in 6 of 8 rats) were observed in plots: $\mathrm{dP} / \mathrm{dt}_{\max }-\mathrm{RL}(\mathrm{e})$, diastolic area $(\mathrm{l}), \mathrm{dP} / \mathrm{dt} t_{\min }(\mathrm{m}), \mathrm{dP} / \mathrm{dt}_{\min }$ delay $(\mathrm{o})$,

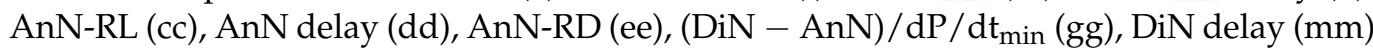
and DiN-RD (nn). The hysteresis cross-relationships (at least in 6 of 8 rats) were observed

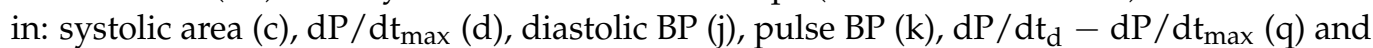
AnN - 1Max (rr). 
3.4. Comparison of Non-Hysteresis/Hysteresis Relationships of $\mathrm{Na}_{2} \mathrm{~S}$ with Published Relationships of GSNO

In our previous study, we evaluated the non-hysteresis/hysteresis relationships between HPs to systolic BP after GSNO administration [4]. Here, we compared the trends of the non-hysteresis/hysteresis "patterns" of $\mathrm{Na}_{2} \mathrm{~S}$ and GSNO (Figure 4). The comparison revealed that the "patterns" of $14 \mathrm{HPs}$ were similar for both compounds. The following HPs showed opposite "patterns": $\mathrm{dP} / \mathrm{dt}_{\max }(\mathrm{d})$, diastolic BP $(\mathrm{j})$, pulse BP $(\mathrm{k})$, diastolic area (l), dP/dt min delay (o), dP/dt $t_{d}-d P / d t_{\max }(\mathrm{q}), \mathrm{dP} / \mathrm{dt}_{\mathrm{d}}-\mathrm{dP} / \mathrm{dt}_{\min }(\mathrm{r}), \operatorname{DinN}(\mathrm{kk}), \mathrm{DiN}$ delay $(\mathrm{mm}), \mathrm{DiN}-\mathrm{AnN}(\mathrm{oo})$, and $(\mathrm{DiN}-\mathrm{AnN}) / \mathrm{dP} / \mathrm{dt}_{\mathrm{min}}(\mathrm{pp})^{\prime}$. The other eight HPs showed different correlations, e.g., non-hysteresis/hysteresis vs. no "patterns" for heart rate (b), dP/dt $(\mathrm{f}), d P / d t_{d}-R L(g), d P / d t_{d}-d P / d t_{\max }(h), d P / d t_{d}-d P / d t_{\min }(\mathrm{i}), d P / d t_{d}$ delay (p), AnN-RL (cc), and (DiN - AnN)/dP/dt $\max (\mathrm{qq})$. The non-hysteresis/hysteresis was not possible to evaluate in the case of augmentation index for both compounds (jj).

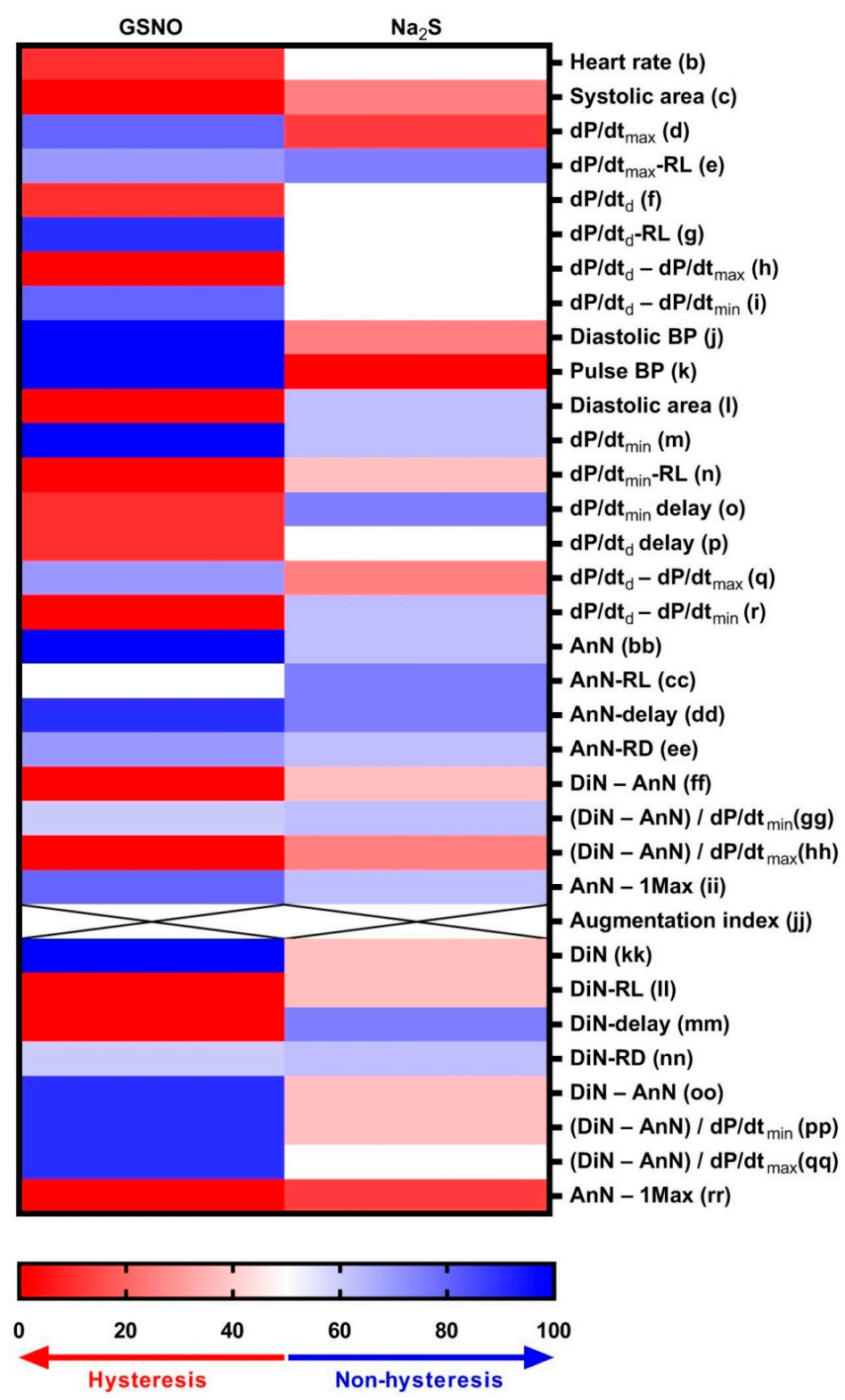

Figure 4. Comparison of the non-hysteresis (blue) or hysteresis (red) "patterns" between HPs to systolic BP after $10 \mu \mathrm{mol} \mathrm{kg}^{-1} \mathrm{H}_{2} \mathrm{~S}(\mathrm{n}=8)$ and $32 \mathrm{nmol} \mathrm{kg}^{-1} \mathrm{GSNO}(\mathrm{n}=10$, data from Figure 3 in Reference [4]) administration. Data are expressed as the percent of rats showing the non-hysteresis relationship. 


\subsection{Effect of $\mathrm{H}_{2} \mathrm{~S}$ on Distinct Fluctuation of Diastolic BP}

The bolus administration of $\mathrm{H}_{2} \mathrm{~S}$ also influenced a minor fluctuation of diastolic BP (Figure 5 and Figures S17-S23) that is clearly seen from the measurement of the time interval between AnN (point d in Figure S1A) and diastolic BP (point a1 or a2 in Figure S1B). This time interval (d-a1) or (d-a2) can be depicted as the time-dependent plot of AnN delay (Figure 5A, plot (dd)) and Figure 5B,C at a higher time resolution. The higher value of $\mathrm{AnN}$ delay in ms (Figure $5 \mathrm{~A}(\mathrm{dd}), \mathrm{B}, \mathrm{C}$ ) indicates that diastolic $\mathrm{BP}$ (in $\mathrm{mmHg}$ ) at point a1 was lower than at point a2. The time dependence of $\mathrm{AnN}$ delay more or less reflected the time-dependent changes of systolic BP (Figure 5A, plot (aa)) and the position of AnN in mmHg (Figure 5A, plot (bb)). The comparison of the fluctuation between a1 and a2 values at single pulses, expressed as the ratio of $\mathrm{a} 1 /(\mathrm{a} 1+\mathrm{a} 2)$ pulses, increased $\sim 5-12 \mathrm{~s}$ after the $\mathrm{H}_{2} \mathrm{~S}$ administration, when systolic $\mathrm{BP}$ reached the minimum and decreased after $120 \mathrm{~s}$ (Figure 5D).
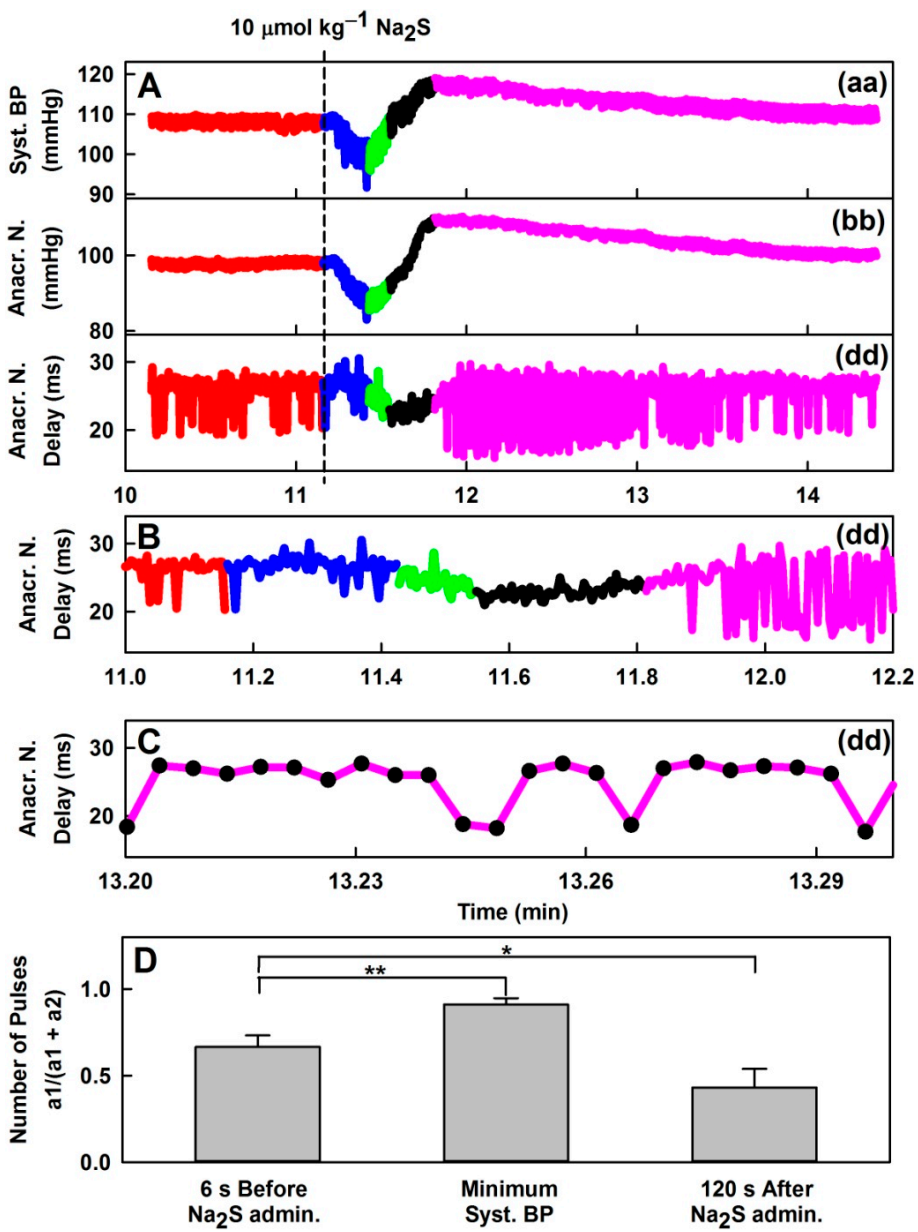

Figure 5. Representative non-filtered time-dependent effect of $10 \mu \mathrm{mol} \mathrm{kg}{ }^{-1} \mathrm{Na}_{2} \mathrm{~S}$ on three HPs. (A) systolic BP (Syst. BP, mmHg) (aa), AnN (Anacr. N., mmHg) (bb) and AnN delay (Anacr. N. delay, $\mathrm{ms}$ ) (dd); (the 10-15 min period is shown). (B) The fluctuation of $\mathrm{AnN}$ delay (dd); (11-12 min) reflects the time interval fluctuation between a1 and a2 points (Figure S1B). The higher value of AnN delay in $\mathrm{ms}$ indicates that diastolic BP at point a1 was lower than at point a2. (C) The fluctuation between a1 and 2 points in pulses (black circles) recorded at high resolution at $120 \mathrm{~s}$ after the $10 \mu \mathrm{mol} \mathrm{kg}{ }^{-1} \mathrm{Na}_{2} \mathrm{~S}$ administration. Data were taken from Figure S8. (D) Comparison of the ratio of $\mathrm{a} 1 /(\mathrm{a} 1+\mathrm{a} 2)$ pulses in $6 \mathrm{~s}$ long interval: Starting $6 \mathrm{~s}$ before the $10 \mu \mathrm{mol} \mathrm{kg}{ }^{-1} \mathrm{Na}_{2} \mathrm{~S}$ administration; from $3 \mathrm{~s}$ before to $3 \mathrm{~s}$ after the minimum of systolic BP, and $120 \mathrm{~s}$ after the $10 \mu \mathrm{mol} \mathrm{kg}{ }^{-1} \mathrm{Na}_{2} \mathrm{~S}$ administration. Data represent means \pm SEM. Statistically significant differences between group means were determined by one-way repeated-measures ANOVA ( $p<0.0001)$ with Dunnett's post-hoc test $\left({ }^{*} p<0.05,{ }^{* *} p<0.01, \mathrm{n}=8\right)$. For the explanation of (aa), (bb) and (dd) plots see the Description of the Table 1 and Figure S1. 


\subsection{Comparison of $\mathrm{Na}_{2} \mathrm{~S}, \mathrm{GSNO}$ and $\mathrm{SSNO}^{-}$-Mix Effects on Rat BP}

It is known that GSNO and $\mathrm{H}_{2} \mathrm{~S}$ influence $\mathrm{BP}$ and interact together to form a mixture of several bioactive products. Nitrosopersulfide $\left(\mathrm{SSNO}^{-}\right)$is one of the major products of this interaction. Therefore, we termed the mixture as the $\mathrm{SSNO}^{-}$-mix. Here, we compared the effects of $\mathrm{Na}_{2} \mathrm{~S}$, GSNO and $\mathrm{SSNO}^{-}$-mix on rat BP. Bolus administration of 40,80, 160 and $320 \mathrm{nmol} \mathrm{kg}^{-1} \mathrm{Na}_{2} \mathrm{~S}$ did not affect $\mathrm{BP}$, whereas the administration of 4, 8, 16 and $32 \mathrm{nmol} \mathrm{kg}{ }^{-1}$ of NO-donor GSNO transiently decreased BP in a concentration-dependent manner (Figure 6). $\mathrm{SSNO}^{-}$-mix applied at a 10:1 molar ratio (by dilution of stock solution prepared by the reaction of $10 \mathrm{mmol} \mathrm{L}^{-1} \mathrm{Na}_{2} \mathrm{~S}$ with $1 \mathrm{mmol} \mathrm{L}^{-1}$ GSNO to final bolus administrations of $\mathrm{Na}_{2} \mathrm{~S}: \mathrm{GSNO}$ at a ratio of 40:4; 80:8; 160:16; and 320:32 in $\mathrm{nmol} \mathrm{kg}^{-1}$ ) had a minor effect on BP.
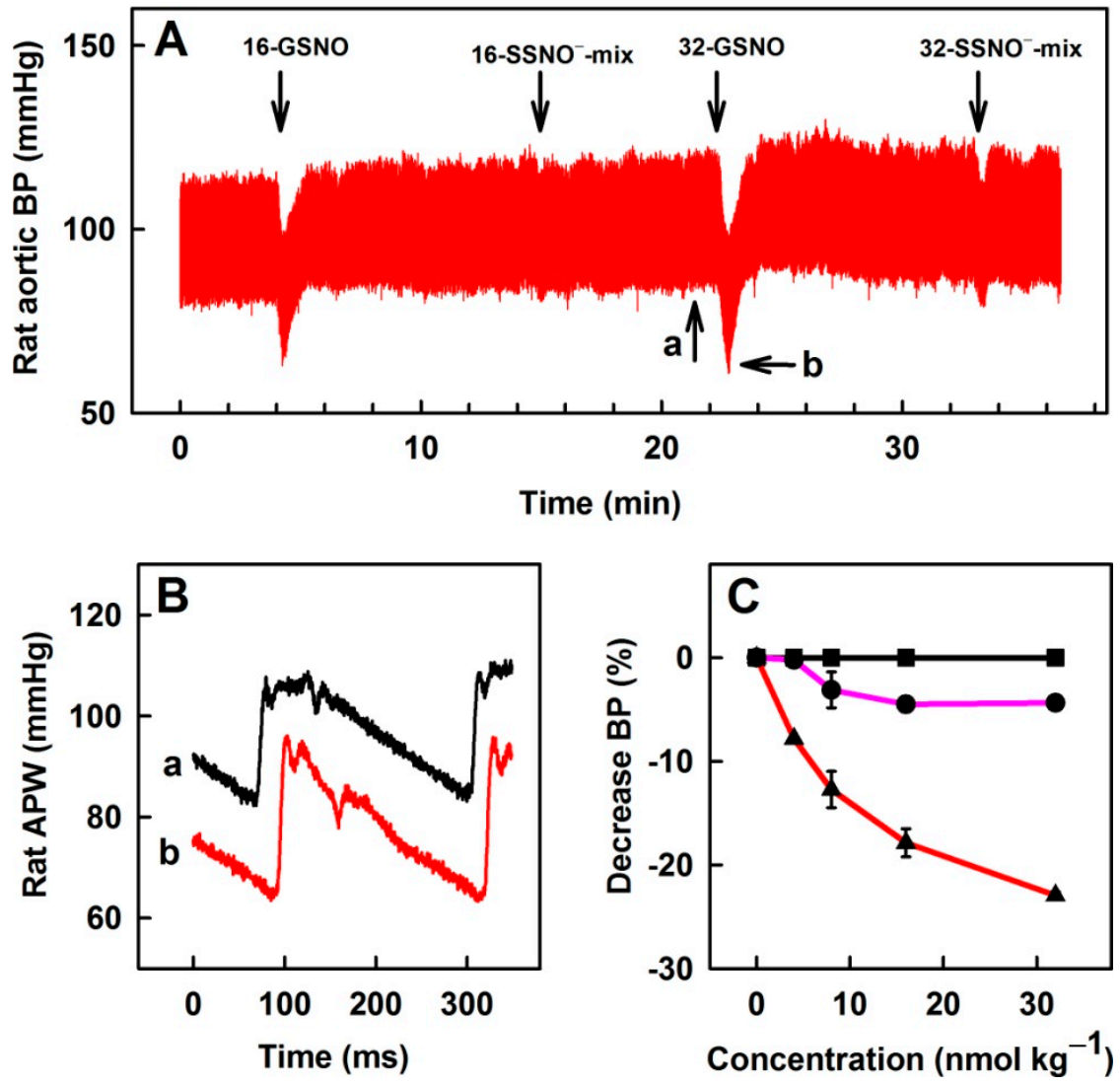

Figure 6. Effects of i.v. bolus administration of 16 and $32 \mathrm{nmol} \mathrm{kg}^{-1}$ GSNO (16- and 32-GSNO), 16 and $32 \mathrm{nmol} \mathrm{kg}^{-1} \mathrm{SSNO}^{-}$-mix on BP in anesthetized rat (A) and the representative rat arterial pulse waveforms (B) before (a) and after (b) the administration of $32 \mathrm{nmol} \mathrm{kg}{ }^{-1}$ GSNO. Comparison of the concentration-dependent effects of GSNO (red), $\mathrm{SSNO}^{-}$-mix (pink) and $\mathrm{Na}_{2} \mathrm{~S}$ (black) on $\mathrm{BP}(\mathrm{C})$; $\mathrm{n}=5$ rats; number of administrations for each concentration $\geq 2$. Data represent means $\pm S E M$.

The comparison of $\mathrm{Na}_{2} \mathrm{~S}, \mathrm{GSNO}$ and $\mathrm{SSNO}^{-}$-mix effects on rat BP was also studied in the condition of a decreased NO bioavailability. It has been shown that L-NAME, an inhibitor of nitric oxide synthase (NOS), decreased NO bioavailability and significantly influenced HPs [6]. Particularly, L-NAME $\left(25 \mathrm{mg} \mathrm{kg}^{-1}\right)$ significantly increased BP and influenced shape of APW (Figure 7). Bolus administration of $\mathrm{Na}_{2} \mathrm{~S}$ at concentrations $40-320 \mathrm{nmol} \mathrm{kg}^{-1}$ did not significantly affect BP. However, GSNO at the concentrations 4-32 nmol kg ${ }^{-1}$ transiently and pronouncedly decreased BP in a concentration-dependent manner in the presence of L-NAME (Figure 7). However, $\mathrm{SSNO}^{-}$-mix $\left(\mathrm{Na}_{2} \mathrm{~S}: \mathrm{GSNO} ; 80: 8\right.$; 160:16; and 320:32 in nmol kg-1) had only a minor effect on BP. 

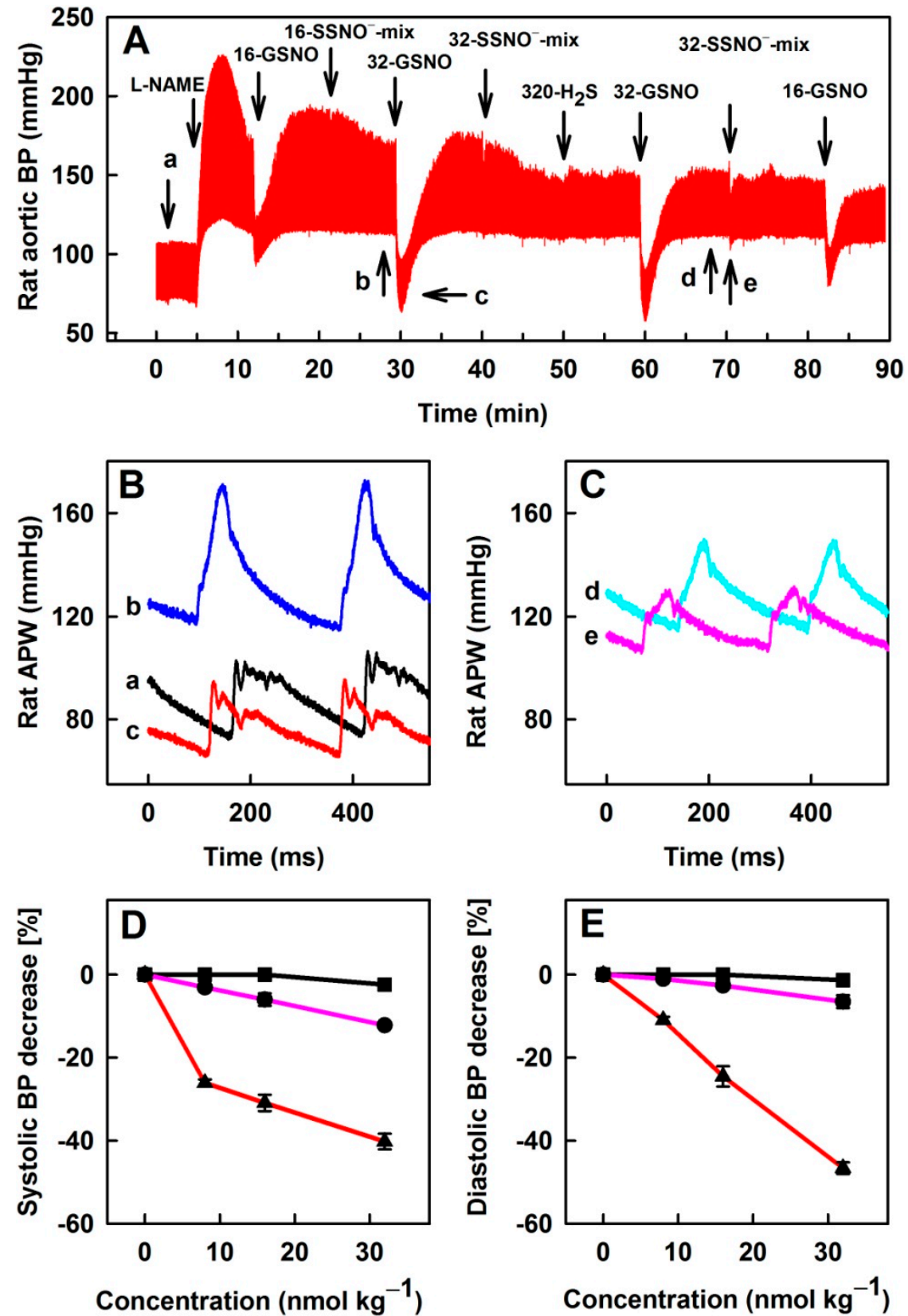

Figure 7. Effects of i.v. bolus administration of 16 and $32 \mathrm{nmol} \mathrm{kg}^{-1} \mathrm{GSNO}$ (16- and 32-GSNO), 16 and $32 \mathrm{nmol} \mathrm{kg}^{-1} \mathrm{SSNO}^{-}$-mix and $320 \mathrm{nmol} \mathrm{kg}^{-1} \mathrm{Na}_{2} \mathrm{~S}\left(320-\mathrm{H}_{2} \mathrm{~S}\right)$ on BP in anesthetized rat in the presence of $25 \mathrm{mg} \mathrm{kg}^{-1} \mathrm{~L}-\mathrm{NAME}$ (A) and the representative rat arterial pulse waveforms $(\mathbf{B}, \mathbf{C})$ before the administration of L-NAME (a), before (b) and after (c) the administration of $32 \mathrm{nmol} \mathrm{kg}^{-1}$ GSNO in the presence of L-NAME; and before (d) and after (e) the administration of $32 \mathrm{nmol} \mathrm{kg}^{-1}$ $\mathrm{SSNO}^{-}$-mix in the presence of L-NAME. Comparison of the concentration-dependent effect of GSNO (red), $\mathrm{SSNO}^{-}$-mix (pink) and $\mathrm{Na}_{2} \mathrm{~S}$ (black) on systolic (D) and diastolic $\mathrm{BP}(\mathrm{E}) ; \mathrm{n}=4$ rats; number of administrations for each concentration $\geq 2$. Data represent means $\pm S E M$.

\section{Discussion}

This work is a continuation of studies based on the hypothesis that it is possible to significantly characterize the cardiovascular system in physiological and patho-physiological conditions just from the shape of APW [4-6]. To characterize the cardiovascular system from APW, the connections between "unique patterns" of APW parameters and specific physiological and patho-physiological conditions must be known. Effects of drugs on APW, for example specific inhibitors/activators of ion channels or regulation enzymes, can 
help to find these "patterns" of APW parameters specific for particular patho-physiological conditions of the cardiovascular system. Our previous studies indicate that the recording system used in our work detects subtle changes of APW with sufficient reproducibility under equal experimental conditions [4]. Using this approach, we characterized timedependent changes of APW caused by i.v. administration of $\mathrm{H}_{2} \mathrm{~S}$, and compared these changes with the effects of NO-donor GSNO and with the effects of $\mathrm{H}_{2} \mathrm{~S} / \mathrm{GSNO}$ interaction mixture $\left(\mathrm{SSNO}^{-}\right.$-mix). It is noticed that the results were obtained in rats under anesthesia.

Reproducibility of the effects of $\mathrm{H}_{2} \mathrm{~S}$ on HPs, their cross-relationships and nonhysteresis/hysteresis "patterns" were significantly lower than the reproducibility of the effects for the NO-synthase inhibitor L-NAME and NO-donor GSNO [4-6]. It might result from numerous interactions of $\mathrm{H}_{2} \mathrm{~S}$ with different components of the cardiovascular system, which were reported previously [21]. Additionally, the interaction of $\mathrm{H}_{2} \mathrm{~S}$ with biological disulfides (RSSR) results in the formation of equilibrium of various sulfur species, e.g., $\mathrm{H}_{2} \mathrm{~S}, \mathrm{RSH}, \mathrm{RSSR}, \mathrm{RSSH}$ and RSSSR, which may be responsible for its diverse activity [22]. These may contribute to the explanation of dissimilar effects of $\mathrm{H}_{2} \mathrm{~S}$ on single HPs, as discussed below.

From the time-dependent $\mathrm{H}_{2} \mathrm{~S}$ effects, it is evident that most of the $34 \mathrm{HPs}$ did not follow the time-dependent changes of systolic BP and that nearly each HP showed a different time-dependent response to $\mathrm{H}_{2} \mathrm{~S}$ (Figure 1 and Figures S2-S8). These results indicate that $\mathrm{H}_{2} \mathrm{~S}$ influences each of the $35 \mathrm{HPs}$ differently, confirming specific "patterns" of responses included in the shape of APW. $\mathrm{H}_{2} \mathrm{~S}$ transiently decreased systolic BP similarly to GSNO, but 10 out of $35 \mathrm{HPs}$ showed diverse trends for $\mathrm{H}_{2} \mathrm{~S}$ and GSNO, indicating different "patterns" of their effects on hemodynamics, based on different signaling pathways.

In order to look for more detailed "patterns" of effects of $\mathrm{H}_{2} \mathrm{~S}$ on the cardiovascular system, the time-dependent changes between HPs, described as their cross-relationships, were evaluated. Each of the cross-relationship between 34 HPs and the systolic BP (Figure 2 and Figures S9-S15) showed a specific "pattern", indicating that various signaling pathways influence the shape of APW after the administration of $\mathrm{H}_{2} \mathrm{~S}$. Some of the cross-relationships showed non-hysteresis or hysteresis loops (Figure 3). Similarly, as in our previous studies $[4,5]$, it is suggested that the non-hysteresis of the cross-relationship between two particular HPs indicates a direct connection between the signaling pathways regulating these two HPs, whereas hysteresis indicates that the signaling pathways are connected indirectly. The direct or indirect connections of signaling pathways regulating the connection between two HPs are also considered as a "pattern" for $\mathrm{H}_{2} \mathrm{~S}$ action. However, more studies are needed to conclude which of the time-dependent and cross-relationships "patterns" are unique for the $\mathrm{H}_{2} \mathrm{~S}$ action.

The comparison of the non-hysteresis or hysteresis cross-relationships of HPs between $\mathrm{H}_{2} \mathrm{~S}$ (Figure 3) and GSNO (Figure 3C in [4]) showed similar, but also opposite "patterns" for particular HPs (Figure 4). Therefore, we may suggest that some of the HPs are regulated by the activation of the same pathways for both compounds, however others were modulated by different mechanisms.

$\mathrm{NO}$ and $\mathrm{H}_{2} \mathrm{~S}$ coupled signaling pathways in the cardiovascular system are complex and not fully understood $[9,21,23-28]$. The involvement of NO in the regulation of BP is associated with the modulation of activity of various ion channels. For instance, NO signaling leads to an increased activity of large conductance $\mathrm{Ca}^{2+}$-dependent $\mathrm{K}^{+}$channels $\left(\mathrm{BK}_{\mathrm{Ca}}\right)$, resulting in $\mathrm{K}^{+}$efflux, causing hyperpolarization of cell membrane and consequent deactivation of L-Type $\mathrm{Ca}^{2+}$ channels. In addition, $\mathrm{NO}$ may decrease intracellular $\mathrm{Ca}^{2+}$ levels by direct inhibition of L-Type $\mathrm{Ca}^{2+}$ channels, thus reducing $\mathrm{Ca}^{2+}$ influx, leading to smooth muscle relaxation [21,23-26]. Similarly, the effects of $\mathrm{H}_{2} \mathrm{~S}$ on BP are mediated through the modulation of the activity of membrane channels. Several reports show that the $\mathrm{H}_{2} \mathrm{~S}$ induced vasorelaxation is caused by the activation of potassium channels, particularly ATP-sensitive potassium channels $\left(\mathrm{K}_{\mathrm{ATP}}\right)$ or small to medium conductance $\mathrm{K}_{\mathrm{Ca}}$ channels $[21,23,29]$. Furthermore, vascular effects of $\mathrm{NO}$ and $\mathrm{H}_{2} \mathrm{~S}$ are mediated through cyclic guanosine monophosphate (cGMP) signaling. NO increases the cGMP levels by 
activating guanylyl cyclase and $\mathrm{H}_{2} \mathrm{~S}$ inhibits phosphodiesterase activity that catalyzes the degradation of cGMP [30]. In turn, cGMP stimulates the activity of protein kinase G (PKG), leading to the dephosphorylation of myosin light chains (MLC) and smooth muscle relaxation. Alternatively, $\mathrm{H}_{2} \mathrm{~S}$ activates PKG by oxidation and disulfide formation, independently of cGMP signaling [31].

The transient decrease of $\mathrm{BP}$ induced by $\mathrm{H}_{2} \mathrm{~S}$ and $\mathrm{NO}$ may at least partially result from hyperpolarization, closing of voltage-dependent calcium channels and reduction of intracellular $\mathrm{Ca}^{2+}$ or reduction of MLC phosphorylation. We may suggest that the similar responses of the cross-relationships of $\mathrm{HP}_{\mathrm{S}}$ to systolic $\mathrm{BP}$ for $\mathrm{H}_{2} \mathrm{~S}$ and $\mathrm{NO}$ (Table 1) and resembling non-hysteresis/hysteresis "patterns" (Figure 4) reflect the "ion channel signaling pathways" or the "PKG signaling pathway" by both compounds. The different responses of the cross-relationships of $\mathrm{HP}_{\mathrm{S}}$ to $\mathrm{H}_{2} \mathrm{~S}$ and $\mathrm{NO}$ and dissimilar non-hysteresis/hysteresis "patterns" may reflect other pathways that are specific for single compounds. For instance, Nier et al. suggested that the changes in the relative levels of DiN are specific for NO signaling and negatively correlate with $\mathrm{NO}$ bioavailability [32]. Our study showed that $\mathrm{H}_{2} \mathrm{~S}$ decreased the relative level of $\mathrm{DiN}$, indicating that the NO-dependent signaling pathway was activated. Moreover, the relationships between DiN-RL (1l) and systolic BP showed mostly hysteresis "patterns" after GSNO and $\mathrm{Na}_{2} \mathrm{~S}$ administration, implicating that the changes in DiN-RL (1l) are activated at different time points and probably by different signaling pathways than the changes in systolic BP (Figure 4). While having a similar effect on BP, GSNO and $\mathrm{H}_{2} \mathrm{~S}$ affected HPs, which reflect heart functions differently. GSNO had a negative inotropic ( $\left.\mathrm{dP} / \mathrm{dt}_{\max }-\mathrm{RL}\right)$ and lusitropic $\left(\mathrm{dP} / \mathrm{dt}_{\min }-\mathrm{RL}\right)$ effect, however $\mathrm{H}_{2} \mathrm{~S}$ had a minor effect on heart contraction and relaxation. At the same time, $\mathrm{H}_{2} \mathrm{~S}$ decreased heart rate, but GSNO did not affect the heart chronotropy. This is in line with a negative inotropic effect of $\mathrm{H}_{2} \mathrm{~S}$ mediated through the opening of $\mathrm{K}_{\text {ATP }}$ channels and no effect on heart contractile function reported by others [33,34]. For the depressive actions of $\mathrm{NO}$ on contraction and relaxation, desensitization of cardiac myofilaments through the cGMP/PKG pathway was described $[35,36]$. Interestingly, the relationships between $\mathrm{dP} / \mathrm{dt}_{\max }-\mathrm{RL}(\mathrm{e})$ and $\mathrm{BP}$ showed mostly non-hysteresis "patterns", however the $\mathrm{dP} / \mathrm{dt}_{\min }-\mathrm{RL}$ (n) to BP showed mostly hysteresis "patterns" for both compounds (Figure 4). Therefore, we suppose that the effects on heart contraction may be mediated by the same signaling pathways as the effects of the compounds on BP. However, the changes in heart relaxation are postponed in comparison to $\mathrm{BP}$ changes and probably mediated by different signaling pathways.

Several reports propose that the products of $\mathrm{H}_{2} \mathrm{~S}-\mathrm{NO}$ interaction, particularly $\mathrm{SSNO}^{-}$, play an important role in the regulation of $\mathrm{BP}[9,17,18,37]$. Therefore, we have studied the effect of $\mathrm{SSNO}^{-}$-mix on BP. SSNO ${ }^{-}$-mix in the presence or absence of L-NAME had minor effects on BP in comparison to GSNO (Figures 6 and 7). Effects of bolus i.v. administration of $\mathrm{SSNO}^{-}$-mix on BP have been previously studied at concentrations $\geq 30 \mathrm{nmol} \mathrm{kg}^{-1}$ and decreased BP in a concentration-dependent manner [12,14]. The observed minor effects of i.v. administration of $\mathrm{SSNO}^{-}$-mix at low concentrations (Figures 6 and 7) with comparison to GSNO on HPs is in contrast to its published potency to relax isolated aortic rings exvivo, in which the effects of $\mathrm{SSNO}^{-}$-mix was several times more potent and faster than GSNO [37]. It has been suggested that $\mathrm{NO}$ and $\mathrm{HNO}$, among other species formed in the $\mathrm{SSNO}^{-}$-mix, were involved in the vessels relaxation [14,37]. However, in blood a fast inactivation of $\mathrm{NO}$ and $\mathrm{HNO}$ occurs after the interaction with hemoglobin $[38,39]$. While the membrane of red blood cells is permeable to NO, the consumption of NO by red blood cells is reduced by an intrinsic barrier and an extracellular unstirred layer of solvent $[40,41]$. Our data suggest that the products of the $\mathrm{SSNO}^{-}$-mix are decomposed or metabolized faster in the blood than GSNO. From this, it is suggested that, at low concentrations (4-32 $\mathrm{nmol} \mathrm{kg}^{-1}$ ), the $\mathrm{SSNO}^{-}$-mix and/or the products of $\mathrm{SSNO}^{-}$-mix decomposition are almost all quenched by blood components before reaching the surface of vascular endothelial cells, leading to minor effects on BP. We may speculate that the mechanisms limiting the consumption of $\mathrm{NO}$ by red blood cells are less effective in the case of the products formed in the $\mathrm{SSNO}^{-}$-mix due to different physical and chemical properties of 
these species. While in the case of isolated aortic rings, $\mathrm{SSNO}^{-}$-mix and its decomposition products directly interact with the membrane and/or intracellular targets [37]. These results suggest that the formation of $\mathrm{SSNO}^{-}$-mix in blood, but not in the cells, diminishes the effects of $\mathrm{NO}$ on BP.

As discussed in our previous studies [4,6], the physiological origin of anacrotic notch (point d in Figure S1A) and the minor time/pressure fluctuation of diastolic BP (Figure S1A,B, point a-a1 or a2) are not yet fully understood. Effect of $\mathrm{H}_{2} \mathrm{~S}$ on the distinct fluctuation of a1 or a2 (Figure 5) was similar (but not identical) to the effect reported for GSNO [4]. The observations that the points fluctuated between two distinct positions and that the fluctuation was influenced by $\mathrm{H}_{2} \mathrm{~S}$ and GSNO during decreasing/increasing of $\mathrm{BP}$ indicate that it might be a physiological, yet unknown, important cardiovascular phenomenon.

\section{Conclusions}

Our work characterizes novel details of the cardiovascular responses and presents numerous original data characterizing APW by $35 \mathrm{HPs}$ and by their cross-relationships after i.v. administration of $10 \mu \mathrm{mol} \mathrm{kg}{ }^{-1} \mathrm{H}_{2}$ S. Since the effect of $\mathrm{H}_{2} \mathrm{~S}$ on BP was transient, we showed non-hysteresis/hysteresis time-dependent changes of $35 \mathrm{HPs}$, and from their cross-relationships to systolic $\mathrm{BP}$, direct/indirect signaling pathways of the $\mathrm{H}_{2} \mathrm{~S}$ effects were proposed. We assume that the similar responses of $\mathrm{HP}_{\mathrm{S}}$ to $\mathrm{H}_{2} \mathrm{~S}$ and $\mathrm{NO}$, their resembling cross-relationships and non-hysteresis/hysteresis "patterns" reflect the activation of "channels or PKG signaling pathways" by both compounds. In addition, the $\mathrm{H}_{2} \mathrm{~S} / \mathrm{GSNO}$ product $\left(\mathrm{SSNO}^{-}\right.$-mix) at a concentration $\leq 32 \mathrm{nmol} \mathrm{kg}{ }^{-1}$ showed a minor effect on hemodynamics in comparison to GSNO, suggesting that the formation of $\mathrm{SSNO}^{-}$-mix in blood diminished the effect of NO on BP. The observed time-dependent changes of $35 \mathrm{HPs}$, their cross and non-hysteresis/hysteresis relationships may serve as "patterns" for the conditions of a transient decrease/increase of $\mathrm{BP}$ caused by $\mathrm{H}_{2} \mathrm{~S}$.

In summary, the analysis of the hemodynamic effects of $\mathrm{H}_{2} \mathrm{~S}$ is a starting point for the characterization of the cardiovascular system by 35 HPs under physiological conditions. However, further validation of the results in animal models of diseases will be useful and represents a challenge for future studies.

Supplementary Materials: The following are available online at https:/ www.mdpi.com/2218-273 X/11/2/293/s1, Figures S1-S23. Figure S1: The left common carotid artery pulse waveform (APW) in the anesthetized rat, Figures S2-S8: Time-dependent changes of HPs of anesthetized rat after i.v. bolus administration of $10 \mu \mathrm{mol} \mathrm{kg}{ }^{-1} \mathrm{Na}_{2} \mathrm{~S}$ measured in 7 independent experiments, Figures S9-S15: Relationships of HPs to the systolic BP after administration of $10 \mu \mathrm{mol} \mathrm{kg}{ }^{-1} \mathrm{Na}_{2} \mathrm{~S}$ obtained in 7 independent experiments, Figure S16: Number of rats representing the non-hysteresis/hysteresis patterns of the relationships of HPs to systolic BP after administrations of $10 \mu \mathrm{mol} \mathrm{kg}{ }^{-1}$, Figures S17-S23: Time-dependent effect of $10 \mu \mathrm{mol} \mathrm{kg}{ }^{-1} \mathrm{Na}_{2} \mathrm{~S}$ on systolic BP (mmHg), AnN (mmHg) and AnN delay (ms) measured in 7 independent experiments.

Author Contributions: Conceptualization, K.O.; Data curation, L.T., M.G. and K.O.; Formal analysis, L.T., M.G., A.M., L.K., E.O. and K.O.; Funding acquisition, M.G., A.M. and K.O.; Investigation, L.T., M.G., A.M., L.K., E.O. and K.O.; Methodology, A.M., L.K. and K.O.; Supervision, K.O.; Visualization, L.T., M.G., A.M. and K.O.; Writing-original draft, L.T. and K.O.; Writing-review \& editing, L.T., M.G., A.M., E.O. and K.O. All authors have read and agreed to the published version of the manuscript.

Funding: This research was funded by the Slovak Research \& Development Agency, grant numbers APVV-19-0154 to L.K., M.G., A.M., L.T., E.O. and K.O.; the VEGA Grant Agency of the Slovak Republic, grant numbers 2/0079/19 to M.G. and 2/0091/21 to A.M.

Institutional Review Board Statement: The study was conducted according to the guidelines of the Declaration of Helsinki, and approved by the Ethics Committee of Biomedical Research Center of Slovak Academy of Sciences and by the State Veterinary and Food Administration of the Slovak Republic (under number: Ro 3123/17-221, 10.08.2017). 
Data Availability Statement: All findings and conclusions are based on the presented figures in the main text or in the supplementary information. Original source files can be sent from the corresponding author, Karol Ondrias, upon request.

Conflicts of Interest: The authors declare no conflict of interest.

\section{References}

1. O'Rourke, M.F.; Pauca, A.; Jiang, X.-J. Pulse wave analysis. Br. J. Clin. Pharmacol. 2001, 51, 507-522. [CrossRef]

2. Žikić, D. A mathematical model of pressure and flow waveforms in the aortic root. Eur. Biophys. J. 2017, 46, 41-48. [CrossRef]

3. Marais, L.; Pernot, M.; Khettab, H.; Tanter, M.; Messas, E.; Zidi, M.; Laurent, S.; Boutouyrie, P. Arterial Stiffness Assessment by Shear Wave Elastography and Ultrafast Pulse Wave Imaging: Comparison with Reference Techniques in Normotensives and Hypertensives. Ultrasound Med. Bio. 2019, 45, 758-772. [CrossRef]

4. Misak, A.; Kurakova, L.; Berenyiova, A.; Tomasova, L.; Grman, M.; Cacanyiova, S.; Ondrias, K. Patterns and Direct/Indirect Signaling Pathways in Cardiovascular System in the Condition of Transient Increase of NO. Biomed. Res. Int. 2020, $2020,6578213$. [CrossRef]

5. Tomasova, L.; Misak, A.; Kurakova, L.; Grman, M.; Ondrias, K. Characterization of Rat Cardiovascular System by Anacrotic/Dicrotic Notches in the Condition of Increase/Decrease of NO Bioavailability. Int. J. Mol. Sci. 2020, 21, 6685. [CrossRef] [PubMed]

6. Kurakova, L.; Misak, A.; Tomasova, L.; Cacanyiova, S.; Berenyiova, A.; Ondriasova, E.; Balis, P.; Grman, M.; Ondrias, K. Mathematical relationships of patterns of 35 rat haemodynamic parameters for conditions of hypertension resulting from decreased nitric oxide bioavailability. Exp. Physiol. 2020, 105, 312-334. [CrossRef] [PubMed]

7. Wang, R. Physiological implications of hydrogen sulfide: A whiff exploration that blossomed. Physiol. Rev. 2012, 92, 791-896. [CrossRef] [PubMed]

8. Drobná, M.; Misak, A.; Holland, T.; Kristek, F.; Grman, M.; Tomasova, L.; Berenyiova, A.; Cacanyiova, S.; Ondrias, K. Captopril partially decreases the effect of $\mathrm{H}_{2} \mathrm{~S}$ on rat blood pressure and inhibits $\mathrm{H}_{2} \mathrm{~S}$-induced nitric oxide release from S-nitrosoglutathione. Physiol. Res. 2015, 64, 479-486. [CrossRef]

9. Cacanyiova, S.; Berenyiova, A.; Balis, P.; Kristek, F.; Grman, M.; Ondrias, K.; Breza, J.; Breza, J., Jr. Nitroso-sulfide coupled signaling triggers specific vasoactive effects in the intrarenal arteries of patients with arterial hypertension. J. Physiol. Pharmacol. 2017, 68, 527-538.

10. Zhao, W.; Zhang, J.; Lu, Y.; Wang, R. The vasorelaxant effect of $\mathrm{H}_{2} \mathrm{~S}$ as a novel endogenous gaseous $\mathrm{K}_{\mathrm{ATP}}$ channel opener. EMBO J. 2001, 20, 6008-6016. [CrossRef]

11. Geng, B.; Yang, J.; Qi, Y.; Zhao, J.; Pang, Y.; Du, J.; Tang, C. $\mathrm{H}_{2} \mathrm{~S}$ generated by heart in rat and its effects on cardiac function. Biochem. Biophys. Res. Commun. 2004, 313, 362-368. [CrossRef] [PubMed]

12. Szijártó, I.A.; Markó, L.; Filipovic, M.R.; Miljkovic, J.L.; Tabeling, C.; Tsvetkov, D.; Wang, N.; Rabelo, L.A.; Witzenrath, M.; Diedrich, A.; et al. Cystathionine $\gamma$-Lyase-Produced Hydrogen Sulfide Controls Endothelial NO Bioavailability and Blood Pressure. Hypertension 2018, 71, 1210-1217. [CrossRef]

13. Yang, G.; Wu, L.; Jiang, B.; Yang, W.; Qi, J.; Cao, K.; Meng, Q.; Mustafa, A.K.; Mu, W.; Zhang, S.; et al. H $\mathrm{H}_{2} \mathrm{~S}$ as a physiologic vasorelaxant: Hypertension in mice with deletion of cystathionine gamma-lyase. Science 2008, 322, 587-590. [CrossRef]

14. Cortese-Krott, M.M.; Kuhnle, G.G.; Dyson, A.; Fernandez, B.O.; Grman, M.; DuMond, J.F.; Barrow, M.P.; McLeod, G.; Nakagawa, $\mathrm{H}$.; Ondrias, K.; et al. Key bioactive reaction products of the $\mathrm{NO} / \mathrm{H}_{2} \mathrm{~S}$ interaction are $\mathrm{S} / \mathrm{N}$-hybrid species, polysulfides, and nitroxyl. Proc. Natl. Acad. Sci. USA 2015, 112, 4651-4660. [CrossRef]

15. Ali, M.Y.; Ping, C.Y.; Mok, Y.Y.; Ling, L.; Whiteman, M.; Bhatia, M.; Moore, P.K. Regulation of vascular nitric oxide in vitro and in vivo; a new role for endogenous hydrogen sulphide? Br. J. Pharmacol. 2006, 149, 625-634. [CrossRef]

16. Li, L.; Whiteman, M.; Guan, Y.Y.; Neo, K.L.; Cheng, Y.; Lee, S.W.; Zhao, Y.; Baskar, R.; Tan, C.H.; Moore, P.K. Characterization of a novel, water-soluble hydrogen sulfide-releasing molecule (GYY4137): New insights into the biology of hydrogen sulfide. Circulation 2008, 117, 2351-2360. [CrossRef]

17. Cacanyiova, S.; Krskova, K.; Zorad, S.; Frimmel, K.; Drobna, M.; Valaskova, Z.; Misak, A.; Golas, S.; Breza, J.; Breza, J., Jr.; et al. Arterial Hypertension and Plasma Glucose Modulate the Vasoactive Effects of Nitroso-Sulfide Coupled Signaling in Human Intrarenal Arteries. Molecules 2020, 25, 2886. [CrossRef] [PubMed]

18. Cortese-Krott, M.M.; Fernandez, B.O.; Santos, J.L.; Mergia, E.; Grman, M.; Nagy, P.; Kelm, M.; Butler, A.; Feelisch, M. Nitrosopersulfide $\left(\mathrm{SSNO}^{-}\right)$accounts for sustained $\mathrm{NO}$ bioactivity of S-nitrosothiols following reaction with sulfide. Redox Bio. 2014, 2, 234-244. [CrossRef]

19. Bogdándi, V.; Ditrói, T.; Bátai, I.Z.; Sándor, Z.; Minnion, M.; Vasas, A.; Galambos, K.; Buglyó, P.; Pintér, E.; Feelisch, M.; et al. Nitrosopersulfide $\left(\mathrm{SSNO}^{-}\right)$Is a Unique Cysteine Polysulfidating Agent with Reduction-Resistant Bioactivity. Antioxid. Redox Signal. 2020. [CrossRef]

20. Grundy, D. Principles and standards for reporting animal experiments in The Journal of Physiology and Experimental Physiology. J. Physiol. 2015, 593, 2547-2549. [CrossRef]

21. Lee, S.R.; Nilius, B.; Han, J. Gaseous Signaling Molecules in Cardiovascular Function: From Mechanisms to Clinical Translation. Rev. Physiol. Biochem. Pharmacol. 2018, 174, 81-156. [CrossRef] 
22. Bianco, C.L.; Akaike, T.; Ida, T.; Nagy, P.; Bogdandi, V.; Toscano, J.P.; Kumagai, Y.; Henderson, C.F.; Goddu, R.N.; Lin, J.; et al. The reaction of hydrogen sulfide with disulfides: Formation of a stable trisulfide and implications for biological systems. Br. J. Pharmacol. 2019, 176, 671-683. [CrossRef]

23. Gheibi, S.; Jeddi, S.; Kashfi, K.; Ghasemi, A. Regulation of vascular tone homeostasis by $\mathrm{NO}$ and $\mathrm{H}_{2} \mathrm{~S}$ : Implications in hypertension. Biochem. Pharmacol. 2018, 149, 42-59. [CrossRef]

24. Iring, A.; Jin, Y.J.; Albarrán-Juárez, J.; Siragusa, M.; Wang, S.; Dancs, P.T.; Nakayama, A.; Tonack, S.; Chen, M.; Künne, C.; et al. Shear stress-induced endothelial adrenomedullin signaling regulates vascular tone and blood pressure. J. Clin. Investig. 2019, 129, 2775-2791. [CrossRef] [PubMed]

25. Rodrigo, G.C.; Herbert, K.E. Regulation of vascular function and blood pressure by circadian variation in redox signalling. Free Radic. Biol. Med. 2018, 119, 115-120. [CrossRef] [PubMed]

26. Zhao, Y.; Vanhoutte, P.M.; Leung, S.W. Vascular nitric oxide: Beyond eNOS. J. Pharmacol. Sci. 2015, 129, 83-94. [CrossRef]

27. Puzserova, A.; Bernatova, I. Blood pressure regulation in stress: Focus on nitric oxide-dependent mechanisms. Physiol. Res. 2016, 65, S309-s342. [CrossRef]

28. Szabo, C. Hydrogen sulfide, an enhancer of vascular nitric oxide signaling: Mechanisms and implications. Am. J. Physiol. Cell Physiol. 2017, 312, C3-c15. [CrossRef] [PubMed]

29. Tang, G.; Wu, L.; Wang, R. Interaction of hydrogen sulfide with ion channels. Clin. Exp. Pharmacol. Physiol. 2010, 37, 753-763. [CrossRef]

30. Cao, X.; Wu, Z.; Xiong, S.; Cao, L.; Sethi, G.; Bian, J.S. The role of hydrogen sulfide in cyclic nucleotide signaling. Biochem. Pharmacol. 2018, 149, 20-28. [CrossRef]

31. Stubbert, D.; Prysyazhna, O.; Rudyk, O.; Scotcher, J.; Burgoyne, J.R.; Eaton, P. Protein kinase G I $\alpha$ oxidation paradoxically underlies blood pressure lowering by the reductant hydrogen sulfide. Hypertension 2014, 64, 1344-1351. [CrossRef] [PubMed]

32. Nier, B.A.; Harrington, L.S.; Carrier, M.J.; Weinberg, P.D. Evidence for a specific influence of the nitrergic pathway on the peripheral pulse waveform in rabbits. Exp. Physiol. 2008, 93, 503-512. [CrossRef] [PubMed]

33. Xu, M.; Wu, Y.M.; Li, Q.; Wang, X.; He, R.R. Electrophysiological effects of hydrogen sulfide on pacemaker cells in sinoatrial nodes of rabbits. Sheng Li Xue Bao 2008, 60, 175-180. [PubMed]

34. Yong, Q.C.; Hu, L.F.; Wang, S.; Huang, D.; Bian, J.S. Hydrogen sulfide interacts with nitric oxide in the heart: Possible involvement of nitroxyl. Cardiovasc. Res. 2010, 88, 482-491. [CrossRef] [PubMed]

35. Brunner, F.; Andrew, P.; Wölkart, G.; Zechner, R.; Mayer, B. Myocardial Contractile Function and Heart Rate in Mice With Myocyte-Specific Overexpression of Endothelial Nitric Oxide Synthase. Circulation 2001, 104, 3097-3102. [CrossRef] [PubMed]

36. Layland, J.; Li, J.M.; Shah, A.M. Role of cyclic GMP-dependent protein kinase in the contractile response to exogenous nitric oxide in rat cardiac myocytes. J. Physiol. 2002, 540, 457-467. [CrossRef]

37. Berenyiova, A.; Grman, M.; Mijuskovic, A.; Stasko, A.; Misak, A.; Nagy, P.; Ondriasova, E.; Cacanyiova, S.; Brezova, V.; Feelisch, M.; et al. The reaction products of sulfide and S-nitrosoglutathione are potent vasorelaxants. Nitric Oxide 2015, 46, 123-130. [CrossRef]

38. Gladwin, M.T.; Crawford, J.H.; Patel, R.P. The biochemistry of nitric oxide, nitrite, and hemoglobin: Role in blood flow regulation. Free Radic. Biol. Med. 2004, 36, 707-717. [CrossRef]

39. Farmer, P.J.; Sulc, F. Coordination chemistry of the HNO ligand with hemes and synthetic coordination complexes. J. Inorg. Biochem. 2005, 99, 166-184. [CrossRef]

40. Vaughn, M.W.; Huang, K.T.; Kuo, L.; Liao, J.C. Erythrocytes possess an intrinsic barrier to nitric oxide consumption. J. Biol. Chem. 2000, 275, 2342-2348. [CrossRef] [PubMed]

41. Deonikar, P.; Kavdia, M. Contribution of membrane permeability and unstirred layer diffusion to nitric oxide-red blood cell interaction. J. Theor. Bio. 2013, 317, 321-330. [CrossRef] [PubMed] 